\title{
A Hyperbranched Mechanically Interlocked Rotaxane-Type Polymer
}

\author{
Susmita Bhattacharjee, ${ }^{\dagger}$ Caiguo Gong, ${ }^{\mathfrak{f}}$ Jason W. Jones, ${ }^{\S}$ and Harry W. Gibson*
}

Department of Chemistry, Macromolecules and Interfaces Institute, Virginia Polytechnic Institute \& State University, Blacksburg, VA, 24061

* Email: hwgibson@vt.edu; FAX: 540-231-8517.

$\dagger$ Present address: Pushan Renewable Energy, Indore, Madhya Pradesh, India. bhattacharjee_sushmita@yahoo.com

$£$ Present address: ExxonMobil Chemical Co., 5200 Bayway Dr., Baytown, TX, 77520. caiguo.gong@exxonmobil.com

$\S \quad$ Present address: DuPont Chemical Solutions Enterprise, Jackson Laboratory, Route 130 Chambers Works, Deepwater, NJ, USA 08023. jason.w.jones@usa.dupont.com

\begin{abstract}
The interaction of the diacid chloride (2) of N,N'-bis(5"-carboxypentyl)-4,4'bipyridnium bis(hexafluorophosphate) (1) with $m$-phenylene-5'-hydroxymethyl-1',3'-phenylene-32-crown-10 (3) at $-70{ }^{\circ} \mathrm{C}$ led to the in situ formation of a pseudorotaxane $\mathbf{4}$ as an $\mathrm{AB}_{2}$ monomer, which was allowed to polymerize by raising the temperature and adding a catalytic amount of pyridine. The resulting hyperbranched polymer was held together via mechanical bonds formed by threading of the crown ether units by the bipyridinium (paraquat) moieties. The polymer was initially precipitated into aqueous $\mathrm{NH}_{4} \mathrm{PF}_{6}$ to remove any unreacted, water soluble diacid $\mathbf{1}$ to form $\mathbf{5 b}$ and then precipitated from DMSO into aqueous $\mathrm{NH}_{4} \mathrm{PF}_{6}$ to remove any pyridinium monoester 8 complexed with crown ether units in the polymer, leading to $\mathbf{6}$. The hyprerbranched polyester was characterized by ${ }^{1} \mathrm{H}$ NMR and NOESY spectroscopies, FAB and MALDI-TOF mass spectrometry and viscometry. NMR spectroscopy confirmed complete esterification of the crown ether alcohol; $\mathbf{5 b}$ contained 60\% monoesterified paraquat units (8) and 40\% diester moieties (9), while 6 contained only $24 \%$ monoester moieties, which existed primarily as "focal point" units (10), but also as uncomplexed linker units (11). A variety of mechanically linked structures
\end{abstract}


containing cyclic units is possible, including 17 - 19. Mass spectrometry on 6 detected masses up to $16.3 \mathrm{kDa}$, corresponding to a degree of polymerization of 11 units of the diester repeat unit in 17 (and/or isomeric structures). 


\section{Introduction}

Dendrimers are precisely defined molecules in the sense of their uniform branching and essentially monodisperse molecular weights; they possess a high degree of surface functionality and globular shapes, which generally lead to high solubilities and very low solution viscosities. ${ }^{1}$ Dendrimers can be designed to possess segmented structures as regards these surface moieties or the internal repeat unit structures. Additionally dendrimers have internal void spaces that can accept guests, depending on their size and interactions with the internal structural features of the dendrimer. Because of these unique attributes, since their beginnings a few decades ago, dendrimers are now key components in many functional materials systems ranging from catalysts to reaction compartments to photon collectors to gene and drug delivery agents. ${ }^{1 \mathrm{f}-1 \mathrm{~m}, 2}$ The component dendrons have been incorporated into traditional polymer architectures to produce dendrigrafts, ${ }^{1 \mathrm{~h}, 3}$ which possess unusual properties, including high solubility even for rigid rod types of backbones.

A disadvantage of these highly useful materials, dendrons and dendrimers, is their multistep synthesis-purification protocol, often complicated by the use of protection-deprotection schemes. As a result, hyperbranched polymers, three-dimensional polymers quite simply prepared by one-step polycondensations of $\mathrm{AB}_{m}(m \geq 2)$ monomers, have been utilized to mimic some of their properties, even though they are not as precise structurally and are more difficult to characterize. $^{1 \mathrm{~h}, 1 \mathrm{~m}}$ Their potential applications include processing modifiers, ${ }^{1 \mathrm{~m}, 4}$ toughening additives, ${ }^{1 \mathrm{~m}, 5}$ drug delivery vehicles, ${ }^{1 \mathrm{~m}, 6}$ synthesis supporting materials, ${ }^{1 \mathrm{~m}, 7}$ advanced coatings, ${ }^{1 \mathrm{~m}, 8}$ polymeric electrolytes, ${ }^{1 \mathrm{~m}, 9}$ and optical waveguide materials. ${ }^{1 \mathrm{~m}, 10}$ 
Another means of circumventing the tedious synthetic and purification protocols required for dendrimers is to utilize self-assembly methods. ${ }^{11}$ Many examples of such supramolecular approaches have now been reported and provide some relief of the synthetic challenges.

However, although we reported a self-assembly process leading to a hyperbranched rotaxane polymer, ${ }^{12}$ with only a single exception that involved Pd complexes, ${ }^{13}$ no one else has reported application of supramolecular approaches to these systems to our knowledge.

Mechanically interlocked macromolecules of the rotaxane ${ }^{14}$ and catenane ${ }^{15}$ types have been widely sought because of their unique structures and potential functions. ${ }^{16}$ The rotaxanetype interlocked structure is formed when a linear species is locked into the cavity of a cyclic species by two bulky stoppers at the ends of the linear species, while the catenane-type structure contains two or more interlocked cyclic species.

In view of current interest in the fields of dendritic polymers and mechanically interlocked macromolecules, here we report the first mechanically interlocked hyperbranched polymer, whose synthesis was carried out nearly two decades ago. ${ }^{17}$ It was prepared by the polycondensation of an $\mathrm{AB}_{2}$ pseudorotaxane monomer. This rotaxane-type interlocked hyperbranched polymer has a novel topology; all of its generations are connected by non-convalent interactions, compared to reported interlocked dendritic polymers in which only one generation is noncovalently linked. ${ }^{13}$ Considering its low solution viscosity and large number of end groups, this prototypical hyperbranched polymer foreshadows other such systems that can be designed for applications similar to covalent analaogs, but possessing other advantages such as ease of construction and response to external stimuli.

\section{Results and Discussion}

\section{A. Design and Synthesis.}


The general synthetic strategy used herein for preparation of a mechanically interlocked hyperbranched polymer is shown in Scheme 1. The main concept is the application of pseudorotaxane formation from functional cyclic species and linear species to form supramolecular

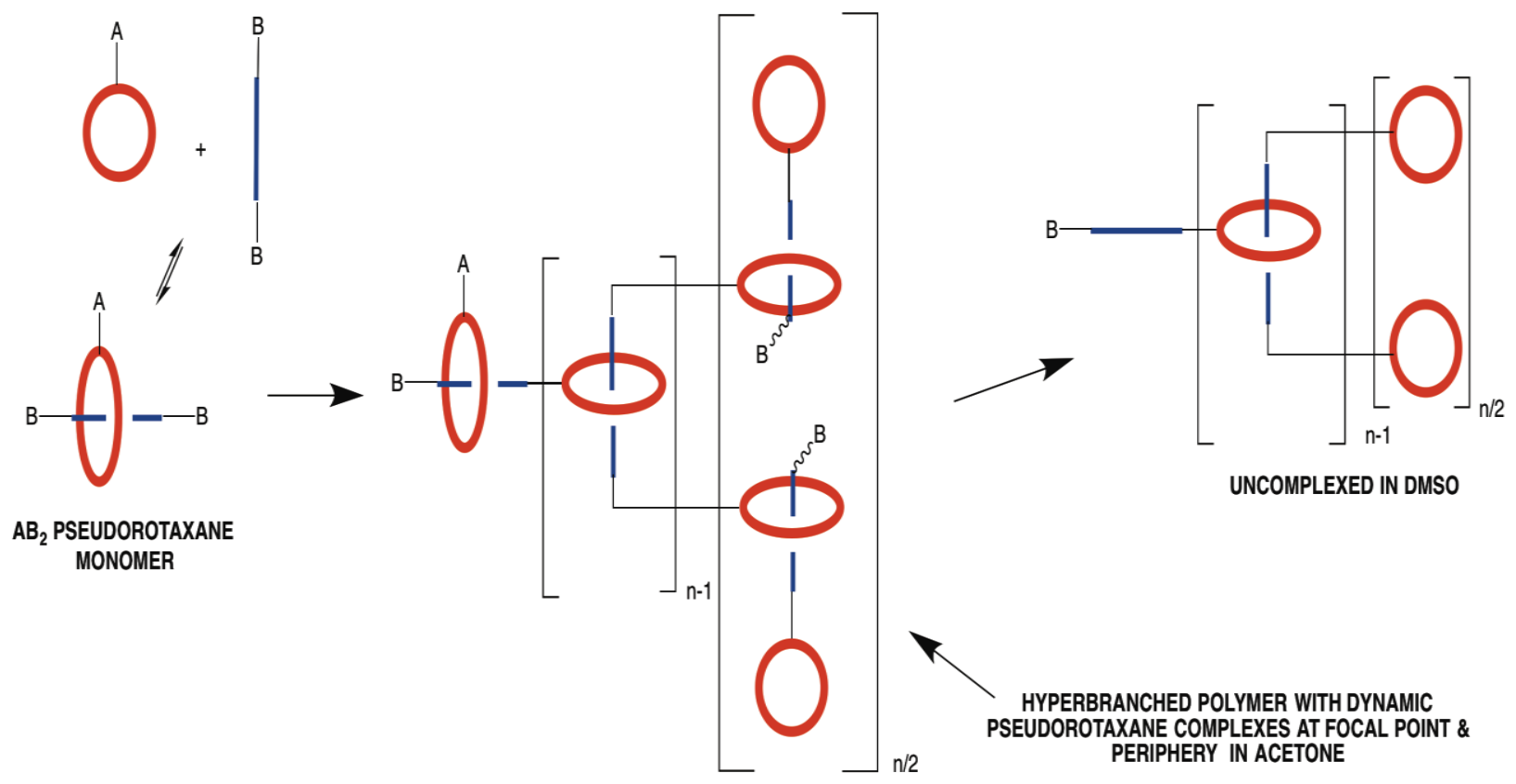

Scheme 1. Cartoon representation of the in situ formation of $\mathrm{AB}_{2}$ pseudorotaxane monomers and their conversion to mechanically linked hyperbranched polymers by polycondensation of A and B moieties. Only fully rotaxanated units can be incorporated into the final polymer because any pseudo- or semirotaxanes present initially are removed by decomplexation with DMSO during the purification process.
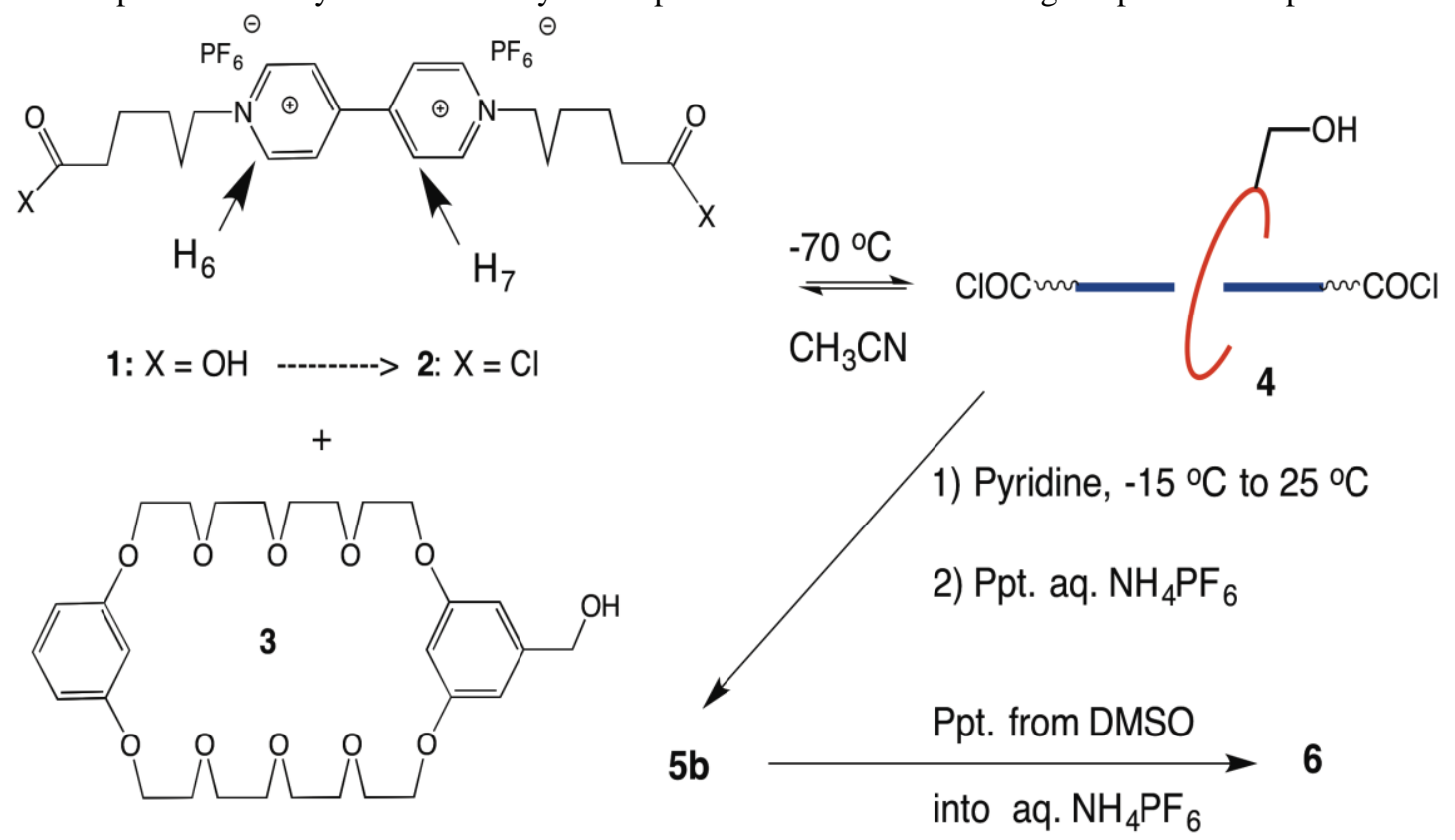

Scheme 2. Reaction scheme for the formation of the mechanically interlocked hyperbranched polyester $\mathbf{6}$ by polycondensation of the $\mathrm{AB}$, pseudorotaxane monomer $\mathbf{4}$ via $\mathbf{5 b}$. 
monomers in situ, i. e., an $\mathrm{AB}_{2}$ pseudorotaxane polycondensation monomer from a monofunctional cyclic and a complementary difunctional linear guest species. The requirements for achieving high molecular weight products are 1) a high degree of association for formation of the threaded structure and 2) efficient polycondensation of the threaded monomer; related parameters are the association constant, the temperature and the concentrations.

In practice, as shown in Scheme 2, in the current study we employed the well studied bis( $m$-phenylene)-32-crown-10/paraquat recognition motif ${ }^{18}$ as monofunctional host and difunctional guest, respectively.

In a preliminary study the complexation of the crown ether alcohol $\mathbf{3}$ with the paraquat diacid 1 was examined in acetone- $d_{6}$ at $21.4,30.0,38.0,46.0$ and $54.0( \pm 0.1){ }^{\circ} \mathrm{C}$ by following the chemical shifts of the aromatic paraquat alpha- $\left(\mathrm{H}_{6}\right)$ and beta-protons $\left(\mathrm{H}_{7}\right)$ in NMR spectra (see SI Figure S1). The fast exchange data were analyzed by the iterative Cresswell-Allred method; ${ }^{18 f, 19}$ association constants for the 1:1 complex varied from 369 to $74 \mathrm{M}^{-1}$ and a van't Hoff plot yielded $\Delta \mathrm{H}=-9.48 \mathrm{kcal} / \mathrm{mol}$ and $\Delta \mathrm{S}=-20.5 \mathrm{eu}$. The association constant of 3 with the dibenzyl ester of $\mathbf{1}(7)$ at $21.6( \pm 0.1){ }^{\circ} \mathrm{C}$ was similarly determined to be the same within experimentalo error. From the thermodynamic parameters, $\Delta \mathrm{H}=9.48$ $\mathrm{kcal} / \mathrm{mol}$ and $\Delta \mathrm{S}=-20.5 \mathrm{eu}$, we estimated the association constants of $\mathbf{1}$ (and by analogy $\mathbf{2}$ ) with $\mathbf{3}$ as $5.4 \times 10^{5}$ and $3.6 \times 10^{3} \mathrm{M}^{-1}$ at -70 and $-15^{\circ} \mathrm{C}$, respectively.

After initial attempts to utilize Mitsonobu conditions failed due to electron transfer from triphenylphosphine to the bipyridinium salt, the paraquat diacid $\mathbf{1}$ was converted by reaction with thionyl chloride into the corresponding diacid chloride 2 , which was mixed with monofunctional $\operatorname{bis}\left(m\right.$-phenylene)-32-crown-10 derivative $3^{20}$ in acetonitrile $(0.25 \mathrm{M}$ each $)$ at $-70{ }^{\circ} \mathrm{C}$ to minimize 
esterification and maximize complexation (ca. 100\% was expected under these conditions), ${ }^{21}$ thereby forming the pseudorotaxane monomer 4 ; then the temperature was allowed to rise slowly. At $-15{ }^{\circ} \mathrm{C}$ pyridine was added to catalyze esterification and later the very viscous reaction system was warmed to room temperature. The in situ generated $\mathrm{AB}_{2}$ pseudorotaxane 4 produced hyperbranched polyester $\mathbf{5 a}$ by esterification as the temperature rose.

By quenching the reaction mixture in aqueous $\mathrm{NH}_{4} \mathrm{PF}_{6}$, any unreacted acid chloride moieties were hydrolyzed and any initial chloride counterions were replaced by $\mathrm{PF}_{6}$ counterions, forming $\mathbf{5 b}$. Since the diacid $\mathbf{1}$ is water-soluble, any unreacted paraquat diacid chloride was effectively removed by simple filtration. The polymer was isolated in $95 \%$ yield. Five more precipitations of the polymer from acetonitrile into aqueous $\mathrm{NH}_{4} \mathrm{PF}_{6}$ were carried out to ensure removal of unreacted diacid and complete conversion to the $\mathrm{PF}_{6}$ salt. Then to remove the mono-esterified paraquat units (8) present as semirotaxanes $18 \mathrm{t}, 18 \mathrm{v}, 18 \mathrm{x}, 18 \mathrm{y}$ (or taco complexes $\quad 18 \mathrm{a}, 18 \mathrm{~g}, 18 \mathrm{~h}, 18 \mathrm{j}-18 \mathrm{~m}, 18 \mathrm{o}, 18 \mathrm{p}, 18 \mathrm{v}, 18 \mathrm{y}, 18 \mathrm{z}, 18 \mathrm{bb}, 18 \mathrm{cc}$ ) threading crown moieties at the periphery of $\mathbf{5 b}$ precipitations from DMSO, a solvent that dissociates these complexes, ${ }^{18 \mathrm{~d}, 22}$ into aqueous $\mathrm{NH}_{4} \mathrm{PF}_{6}$ was carried out to form hyperbranched polyester $\mathbf{6}$. At this point the only components of the polymer were presumed to be monoester 8 and diester $\mathbf{9}$ linked, as

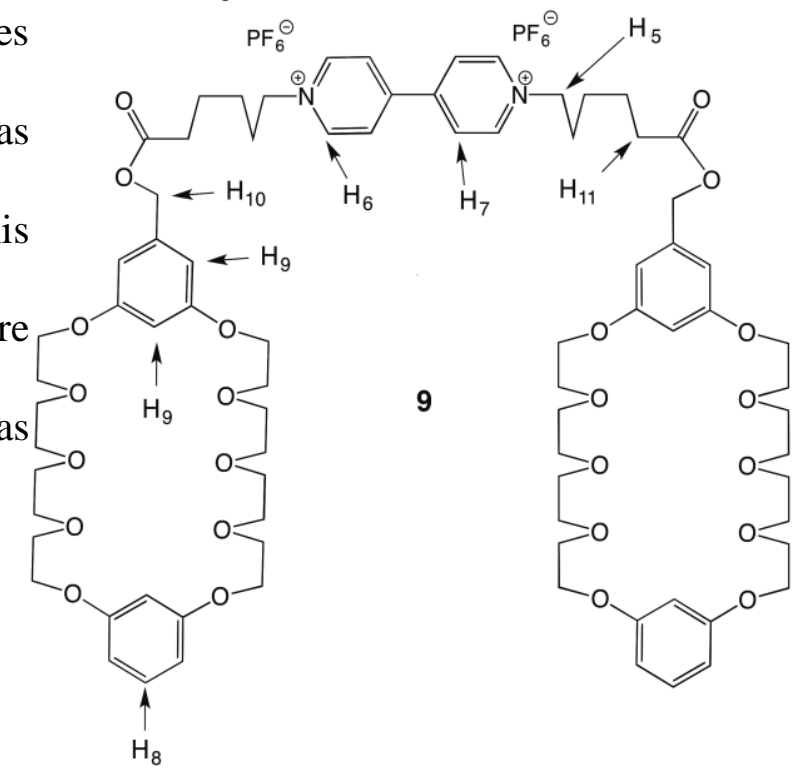


noted below, in a number of different ways through rotaxane (mechanical) linkages.

Low-resolution fast-atom bombardment mass spectometry [in $m$-nitrobenzoic acid (NBA)] on the residue from the aqueous filtrates of the precipitations from DMSO confirmed removal of the monoesterified paraquat species 8: $m / z 1079\left[\mathbf{8}-\mathrm{PF}_{6}\right]^{+}(1.8 \%)$ and $934\left[\mathbf{8}-2 \mathrm{PF}_{6}\right]^{+}(3 \%)$ with the base peak at $\mathrm{m} / \mathrm{z} 135$ for $\left[\mathrm{NBA}-\mathrm{H}_{2} \mathrm{O}\right]^{+}$. No peaks related to paraquat diacid $\mathbf{1}$ were observed in the aqueous filtrate, indicating that there was no paraquat diacid left in $\mathbf{5 b}$ after the initial precipitations into aqueous $\mathrm{NH}_{4} \mathrm{PF}_{6}$. At this point 6 was stable because the peripheral rings of the diester 9 served as blocking groups and prevented dissociation of the rotaxane units.

\section{B. Proton NMR Characterization.}

The proton NMR spectrum of the initially isolated polyester rotaxane/pseudorotaxane $\mathbf{5 b}$ (Figure 1) revealed that all of the alcohol units of crown ether $\mathbf{3}$ had been esterified, as evidenced by loss of the benzylic signal at $4.38 \mathrm{ppm}$ of $\mathbf{3}$ and the appearance of a new signal for benzylic protons $\mathrm{H}_{10}$ of the ester moieties of components 8 and $\mathbf{9}$ at $4.95 \mathrm{ppm}$. For reference, the uncomplexed model dibenzyl ester 7 displayed its benzylic $\mathrm{COOCH}_{2}$ signal at $5.10 \mathrm{ppm}$. There were three sets of signals for the aromatic protons of the paraquat units; the middle signals, consisting of a pair of doublets, were attributed to $\alpha$ - and $\beta$-pyridinium protons $\mathrm{H}_{6}$ and $\mathrm{H}_{7}$ of diester units 9 and the minor signals consisting of four pairs of doublets were attributed to pyridinium protons $\mathrm{H}_{1}, \mathrm{H}_{2}, \mathrm{H}_{3}$ and $\mathrm{H}_{4}$ of mono-ester/mono-acid paraquat units 8 complexed with

peripheral crown ether units. ${ }^{23}$ The integration ratio of these signals $\left(\mathrm{H}_{1}=\mathrm{H}_{2}=\mathrm{H}_{3}=\mathrm{H}_{4}\right)$ confirmed that no diacid 1 remained and vs. $\left(\mathrm{H}_{6}+\mathrm{H}_{7}\right)$ indicated that the paraquat units were $40 \%$ diesterified (9) and 60\% monoesterified units (8) in polymer $\mathbf{5 b}$.

The proton NMR spectrum of polyester 6 [resulting from further precipitation from DMSO to remove complexed paraquat monoester monoacid 8] in acetone- $d_{6}$ is shown in Figure 
$\mathbf{2}$ along with the spectra of guest $\mathbf{1}$ and host $\mathbf{3}$. Every proton on $\mathbf{1}$ and $\mathbf{3}$ underwent a chemical shift change after the formation of the mechanically interlocked hyperbranched polyester 6. The benzylic protons $\left(\mathrm{H}_{10}\right)$

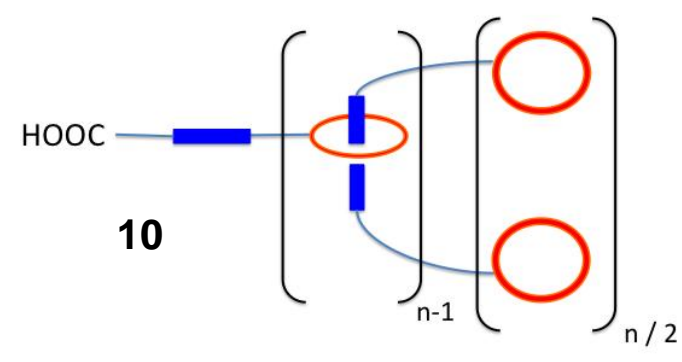
on the crown ether unit had the biggest chemical shift change, $0.48 \mathrm{ppm}$. Three sets of signals

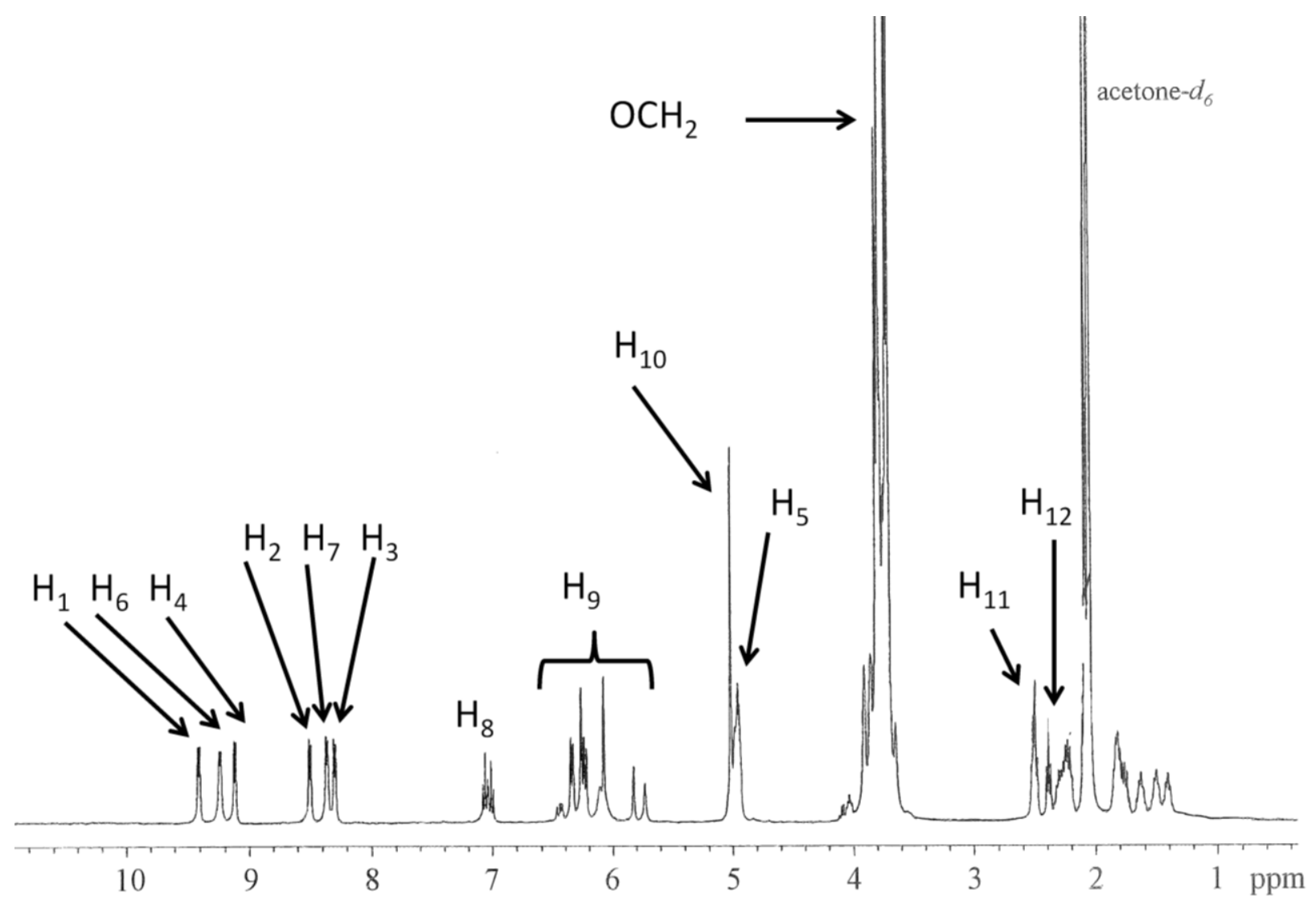

Figure 1. $400 \mathrm{MHz}$ proton NMR spectrum of polyester $\mathbf{5 b}$ in acetone- $d_{6}$ at $22{ }^{\circ} \mathrm{C}$.

corresponding to aromatic pyridinium protons were observed; as in initially isolated polymer $\mathbf{5 b}$ the middle set was identified as due to $\mathrm{H}_{6}$ and $\mathrm{H}_{7}$ of rotaxanated paraquat diester units 9 , while the other two sets of signals were attributed to the asymmetric paraquat monoester units $\left(\mathrm{H}_{1}, \mathrm{H}_{2}\right.$, $\mathrm{H}_{3}$, and $\mathrm{H}_{4}$ ) at the focal point in $\mathbf{1 0}$. This assignment is in keeping with the results for $\mathbf{5 b}$ and was 
confirmed by the NOESY spectrum of 6 (Figure 3); only the major signals for $\mathrm{H}_{6}$ and $\mathrm{H}_{7}$ of the paraquat moieties of diester units $\mathbf{9}$ displayed strong through-space interactions with ethyleneoxy protons on the crown ether units. The concentration dependence of the chemical shifts of $\mathrm{H}_{1}, \mathrm{H}_{2}$, $\mathrm{H}_{3}$, and $\mathrm{H}_{4}$ (see ESI Figure $\mathrm{S} 2$ ) supported this assignment. The dynamic interaction of focal point paraquat and crown ether units in acetone was confirmed by decreased complexation at higher temperatures and increased complexation at low temperatures as indicated by changes in chemical shifts of $\mathrm{H}_{1}, \mathrm{H}_{2}, \mathrm{H}_{3}$, and $\mathrm{H}_{4}$ (see ESI Figures S3). Additional confirmation of this assignment was provided by the results of adding excess paraquat diacid 1: the signals attributed to protons $\mathrm{H}_{1}$ and $\mathrm{H}_{2}$ of the monoester units $\mathbf{8}$ merged with those of $\mathbf{1}$, while those attributed to protons $\mathrm{H}_{3}$ and $\mathrm{H}_{4}$ of the esterified end of $\mathbf{8}$ underwent a downfield shift (see ESI Figure S4). Conversely, upon addition of excess crown ether $\mathbf{3}$ the signals attributed to protons $\mathrm{H}_{1}, \mathrm{H}_{2}, \mathrm{H}_{3}$, and $\mathrm{H}_{4}$ of the monoester units $\mathbf{8}$ shifted upfield, denoting enhanced complexation (see ESI Figure S4). However, the signals for $\mathrm{H}_{6}$ and $\mathrm{H}_{7}$ of the rotaxanated diester paraquat moieties 9 did not shift.

From integrations of these signals $\left(\mathrm{H}_{1}+\mathrm{H}_{2}+\mathrm{H}_{3}+\mathrm{H}_{4}\right.$ vs. $\left.\mathrm{H}_{6}+\mathrm{H}_{7}\right)$ in Figure 2, the ratio of paraquat diester units 9 to monoester paraquat units 8 in $\mathbf{6}$ was estimated to be 3.1:1.0 vs. $0.67: 1.0$ in $\mathbf{5 b}$.

From integrations of signals (7.0-7.2 ppm) corresponding to $\mathrm{H}_{8}$ on the crown ether units and $\mathrm{H}_{1}, \mathrm{H}_{2}, \mathrm{H}_{3}, \mathrm{H}_{4}, \mathrm{H}_{6}$ and $\mathrm{H}_{7}$ on the paraquat moieties, the ratio of the number of crown ether units to the number of paraquat units in $\mathbf{6}$ was $1.92 \pm 0.04: 1.00$ vs. $1.60: 1.00$ in $\mathbf{5 b}$, indicating efficient removal of linear ester-acid guest $\mathbf{8}$ from the semirotaxane units of $\mathbf{5 b}$. Two triplets at $\delta$ $=2.49$ and 2.39 ppm were observed for $\alpha$-carbonyl methylene protons $\left(\mathrm{H}_{11}\right.$ and $\mathrm{H}_{12}$, Figure 2 inset); the former corresponds to ester units and the latter corresponds to acid units. From 
integrations of these two triplets, the ratio of ester to acid groups in $\mathbf{6}$ was estimated to be 6.7:1.0. Thus, this corresponds to about one monoester paraquat unit 8 per 2.8 rotaxanated paraquat diester units 9 on average for $\mathbf{6}$. This ratio roughly agrees with the results from comparison of $\mathrm{H}_{6} / \mathrm{H}_{7}$ with $\mathrm{H}_{1} / \mathrm{H}_{2} / \mathrm{H}_{3} / \mathrm{H}_{4}: 3.1$ diesters per monoester. It should be noted that for interlocked hyperbranched polyester $\mathbf{6}$ every paraquat unit with an acid group is a "focal point" in $\mathbf{1 0}$.

Two triplets $(\delta=7.02$ and $7.07 \mathrm{ppm})$ and a broad distribution of signals $(\delta=5.60-6.40$ ppm) were observed for protons $\mathrm{H}_{8}$ and $\mathrm{H}_{9}$, respectively, in hyperbranched polyester $\mathbf{6}$ in acetone. The minor signals are due to dynamic (temperature and concentration dependent), rapidly exchanging semirotaxane formation between the focal point paraquat group and peripheral crown ether units of $\mathbf{1 0}$ and other species (see below).

The proton NMR spectra of $\mathbf{1}, \mathbf{3}$, and $\mathbf{6}$ in DMSO are shown in Figure 4. Though compared with the situation in acetone, chemical shift changes in DMSO decreased for all of the protons on crown ether and paraquat units in the hyperbranched polyester, the chemical shift changes remain in this dissociating solvent. This confirmed the existence of the mechanically interlocked (rotaxane) structures. It is expected that, as we have observed in closely related systems, ${ }^{24}$ in this solvent the cyclic species are not spatially confined near the paraquat units, but have considerable freedom to move between the constraints of the adjacent macrocycles, because complexation is essentially completely suppressed. Therefore, in DMSO only a triplet was observed for $\mathrm{H}_{8}$ [the small time averaged semirotaxane signal at $7.02 \mathrm{ppm}$ observed in acetone (Figure 2) disappeared] and the distribution of signals corresponding to $\mathrm{H}_{9}$ became narrow in DMSO.

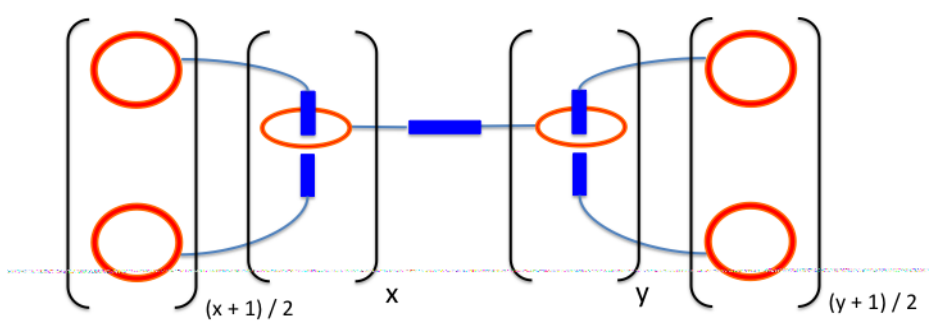


In addition to structures of type $\mathbf{1 0}$, there are other generic types of structures possible for the hyperbranched polyester rotaxane. Another possible structure is $\mathbf{1 1}$, bearing an uncomplexed paraquat unit linking two hyperbranched structures. One structural

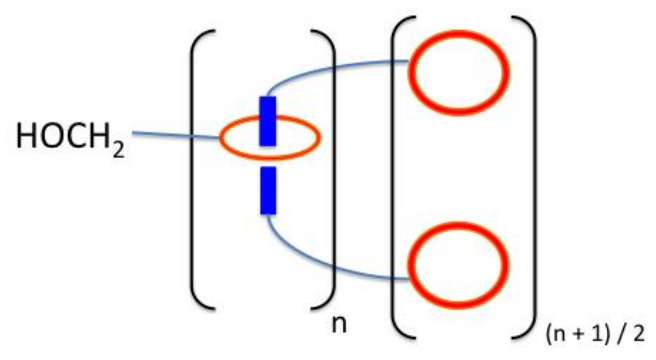

12 family that can be ruled out is represented by 12; it contains a threaded but unesterified crown ether alcohol, which is unlikely in view of the stoichiometry employed and, in fact, not experimentally observed by NMR.

Structures containing only diester units $\mathbf{9}$ are also expected to form. Thus, there is also the possibility of forming cyclic units $\mathbf{1 3}$ - $\mathbf{1 6}$ in analogy to cyclics observed in normal covalent

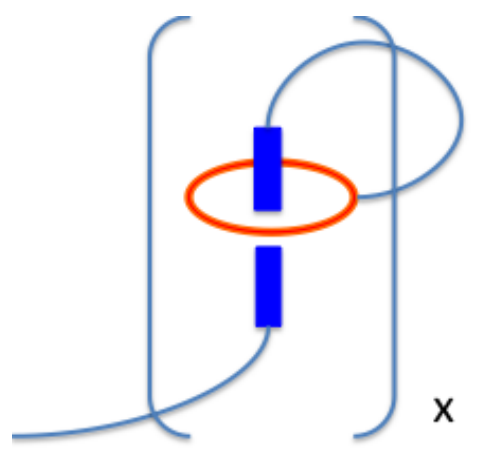

13: $x=1$

14: $x=2$

15: $x=3$

16: $x=4$

Etc.

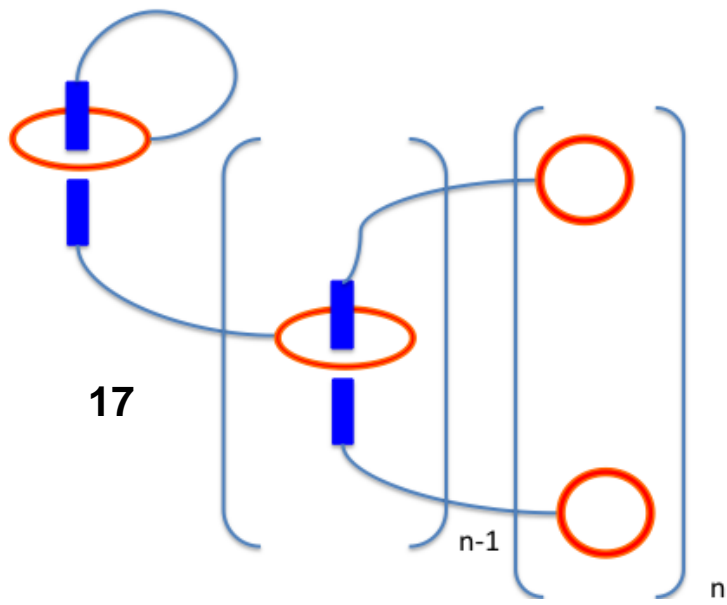

hyperbranched systems. ${ }^{1,25}$ These units constitute focal points in the polyester, e. g., 17. Other cyclics, result in enhanced branching (3-, 4- up to

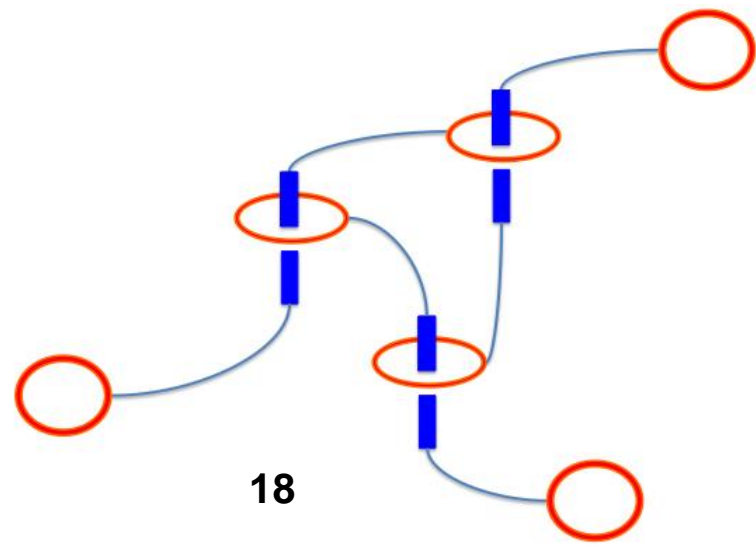
n-fold, respectively). As examples, 18 represents a cyclic trimer end-capped with macrocycles and 19 incorporates a tetrameric cyclic along with "normal" repeat units. 


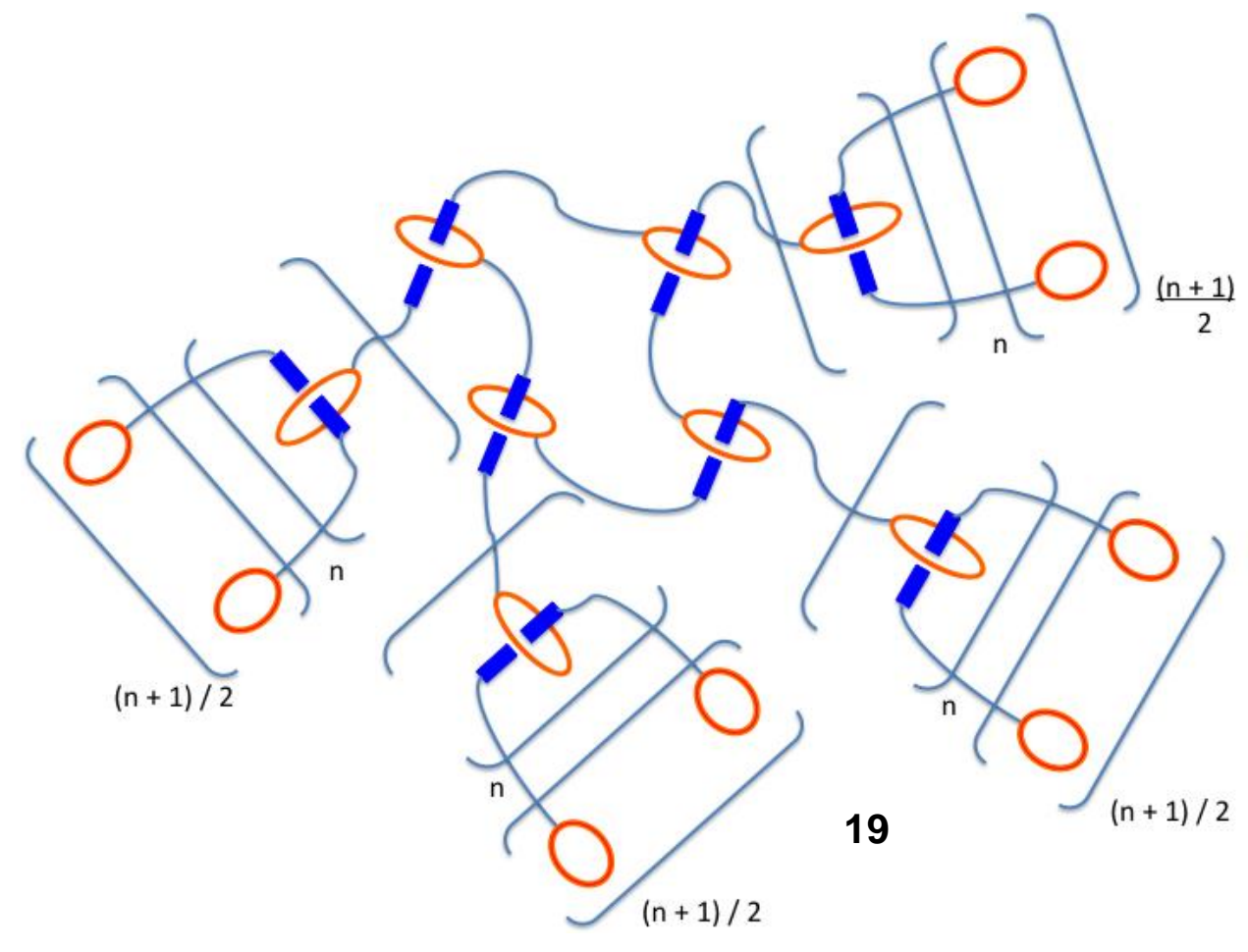




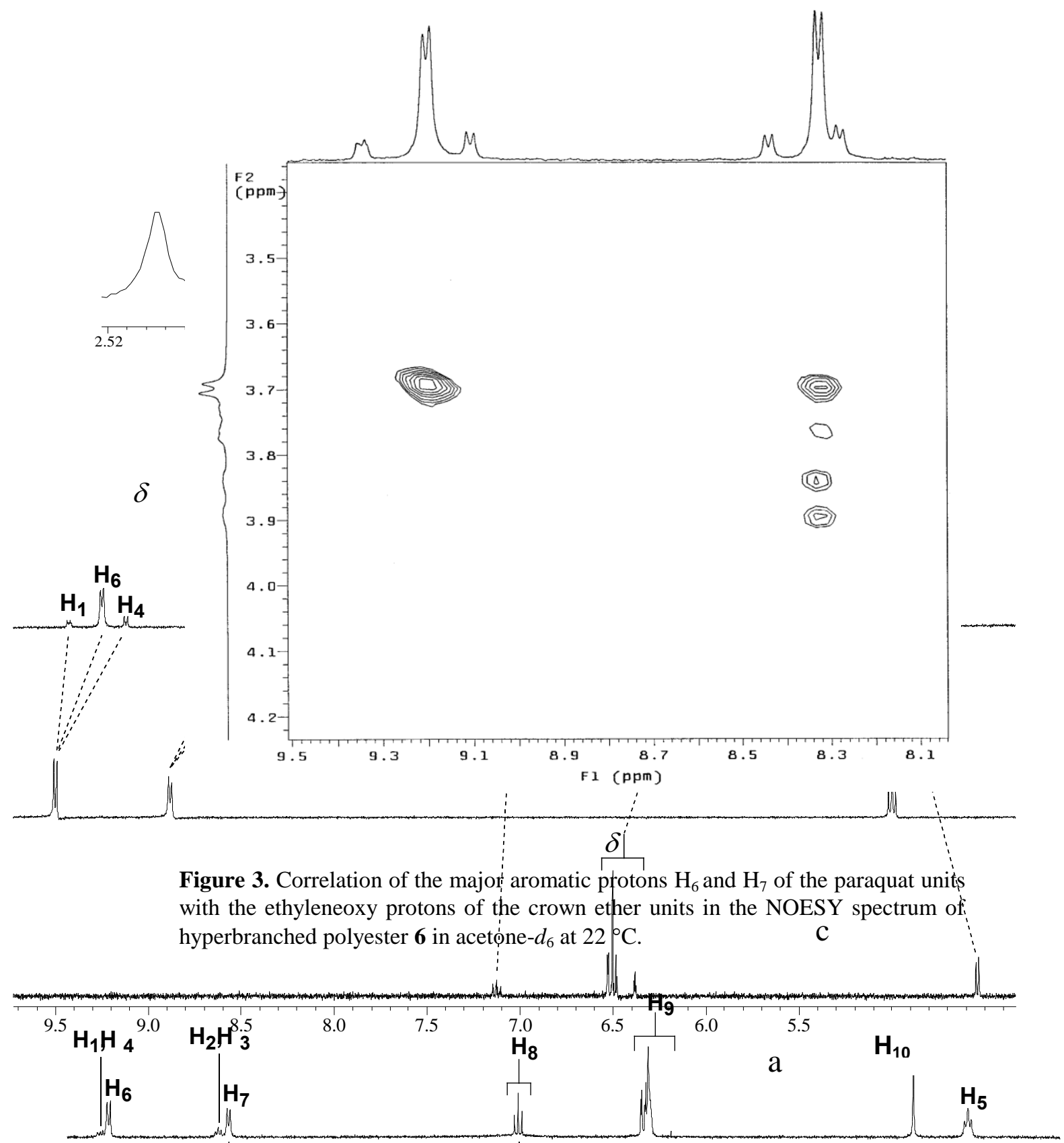

Figure 2: Partial protón NMR spectra $\left(400 \mathrm{MHz}\right.$, acetone- $\left.d_{6}, 22^{\circ} \mathrm{C}\right)$ of (a, top) hyperbranched polyester 6, (b, middle) paraquat diacid 1 and (c, bottom) crobwn ether alcohol 3. The top insert is the upfield region of the proton NMR spectrum of $\mathbf{6}$.

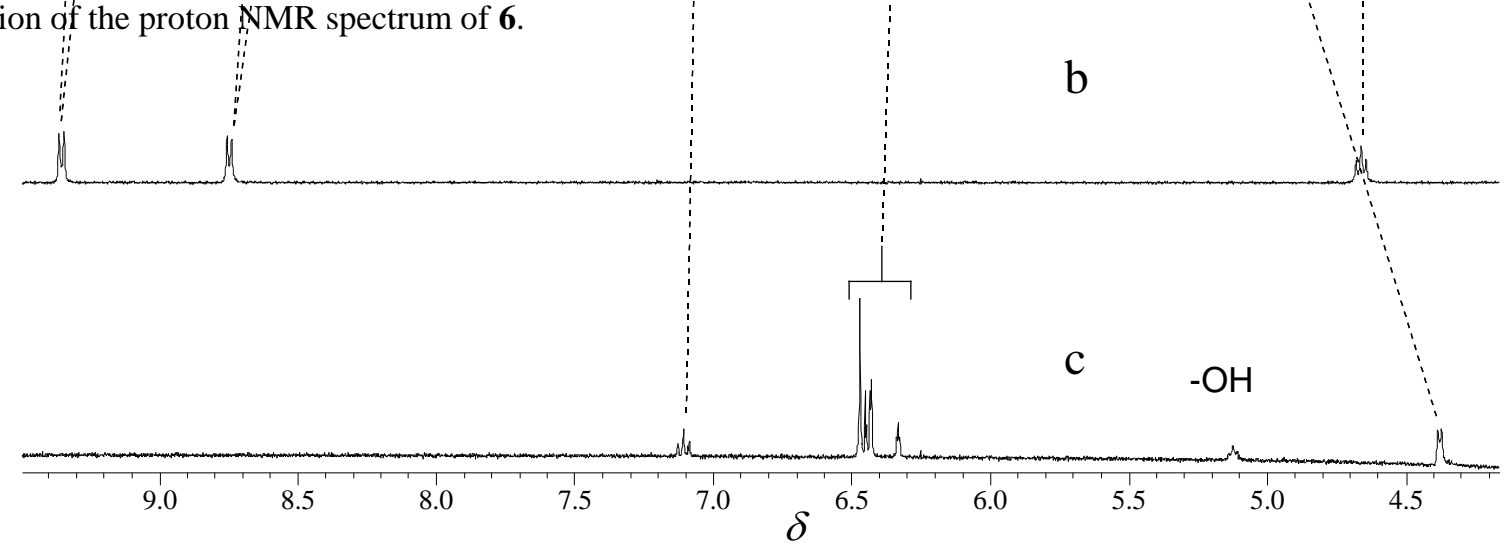

Figure 4. Partial proton NMR spectra (400 $\mathrm{MH}_{4}$ DMSO- $d_{6}, 22{ }^{\circ} \mathrm{C}$ ) of (a, top) hyperbranched polyester $\mathbf{6}$, (b, middle) paraquat diacid $\mathbf{1}$ and (c, bottom) crown ether alcohol $\mathbf{3}$. 


\section{Mass Spectrometry.}

Before the mass spectral results are discussed, it is worth pointing out that all oligomers of types 10, 11 and $\mathbf{1 7}$ - 19 have $>131$ carbon atoms, since $\mathbf{8}$ is $\mathrm{C}_{51}$ and $\mathbf{9}$ is $\mathrm{C}_{80}$; hence the $(\mathrm{M}+1)^{+}$peaks will be more intense than the $\mathrm{M}^{+}$signals. This fact, coupled with the low resolution methods employed at the time, means that $\mathrm{m} / \mathrm{z}$ values within 2 or $3 \mathrm{amu}$ of theoretical values are considered acceptable.

In low resolution (LR) FAB-MS in nitrobenzyl alcohol (NBA) the polyester $\mathbf{5 b}$ after precipitation from acetonitrile into aqueous $\mathrm{NH}_{4} \mathrm{PF}_{6}$ displayed (Figure 5) above m/z 1000 a base peak at $\mathrm{m} / \mathrm{z} 1483$, corresponding to the simple building block diester $\left[\left(9-2 \mathrm{PF}_{6}\right)^{+}\right.$, theory $\mathrm{m} / \mathrm{z}$ 1483]; also present were $\mathrm{m} / \mathrm{z} 1628(48 \%)$ assigned to $\left[\left(9-\mathrm{PF}_{6}\right)^{+}\right.$, theory $\left.\mathrm{m} / \mathrm{z} 1628\right] ; \mathrm{m} / \mathrm{z} 1080$

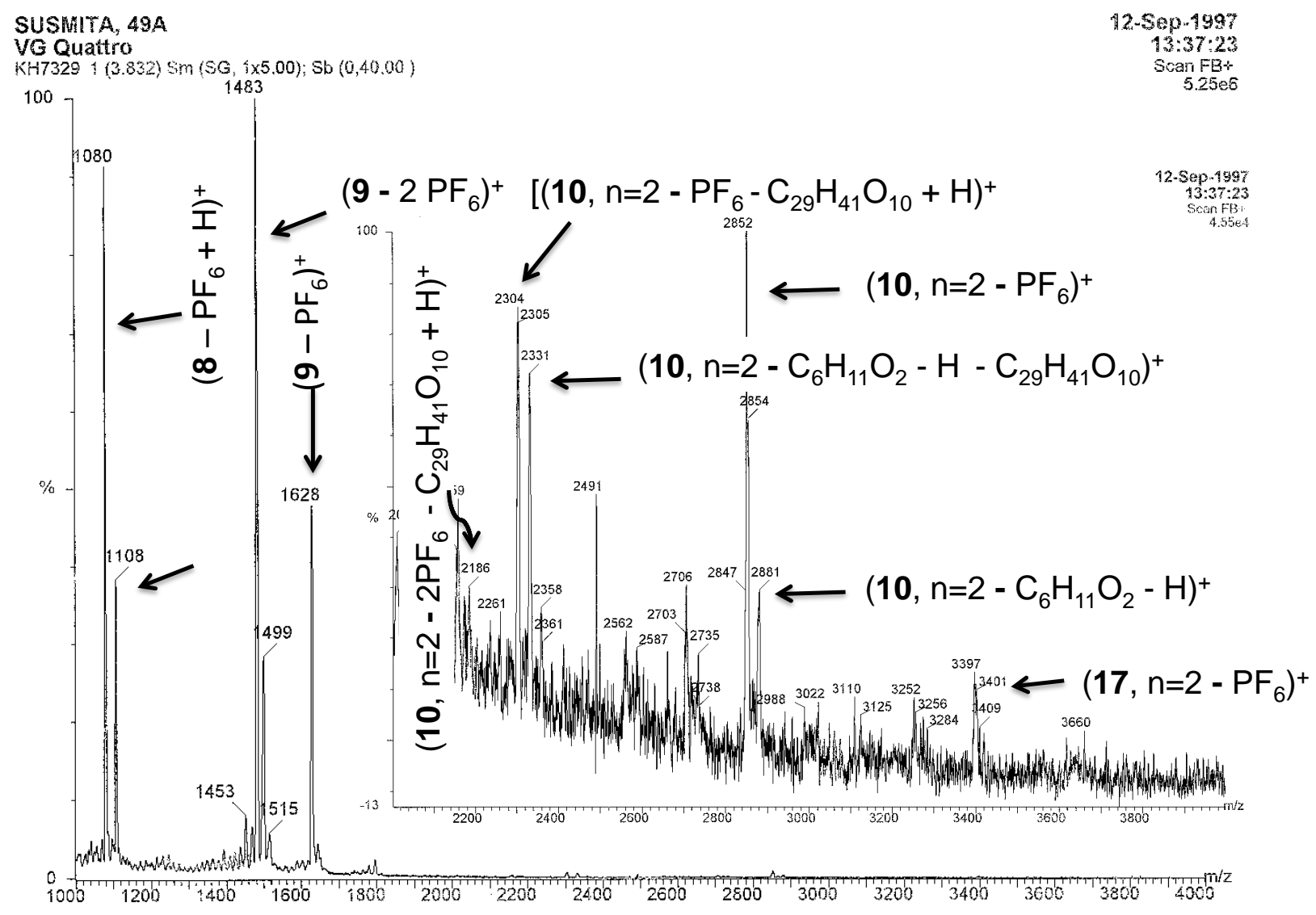

Figure 5. Low resolution FAB mass spectrum of hyperbranched polyester 5b in 3-nitrobenzyl alcohol. The insert for the higher $\mathrm{m} / \mathrm{z}$ values is an expansion of the $\mathrm{y}$-axis by a factor of $\sim 100$. 
$(92 \%)$ assigned to the building block monoester $\left[\left(8-\mathrm{PF}_{6}+\mathrm{H}\right)^{+}\right.$, theory $\left.\mathrm{m} / \mathrm{z} 1080\right]$. The $\mathrm{m} / \mathrm{z}$ $1108(38 \%)$ signal is an artifact derived from use of the instrument to characterize $\mathrm{Sc}_{3} \mathrm{~N} @ \mathrm{C}_{80}$ (exact mass 1109 amu). ${ }^{26}$ Weaker signals $(0.2$ to $1 \%$ ) were observed (in order of decreasing intensity): $\mathrm{m} / \mathrm{z} 2852\left[\left(\mathbf{1 0}, \mathrm{n}=2-\mathrm{PF}_{6}\right)^{+}\right.$, theory $\left.\mathrm{m} / \mathrm{z} 2852\right] ; \mathrm{m} / \mathrm{z} 2304\left[\left(\mathbf{1 0}, \mathrm{n}=2-\mathrm{PF}_{6}-\mathrm{C}_{29} \mathrm{H}_{41} \mathrm{O}_{10}\right.\right.$ $\left(\right.$ crownCH $\left.\left.\mathrm{H}_{2}=549\right)+\mathrm{H}\right)^{+}$, theory $\left.\mathrm{m} / \mathrm{z} 2304\right] ; \mathrm{m} / \mathrm{z} 2331\left[\left(\mathbf{1 0}, \mathrm{n}=2-\left(\mathrm{CH}_{2}\right)_{5} \mathrm{COOH}-\mathrm{H}-\mathrm{C}_{29} \mathrm{H}_{41} \mathrm{O}_{10}\right.\right.$ $($ crownCH 2$))^{+}$, theory $\left.\mathrm{m} / \mathrm{z} 2332\right] ; \mathrm{m} / \mathrm{z} 2881\left[\left(\mathbf{1 0}, \mathrm{n}=2-\left(\mathrm{CH}_{2}\right)_{5} \mathrm{COOH}-\mathrm{H}\right)^{+}\right.$, theory m/z 2881]; $\mathrm{m} / \mathrm{z} 2159\left[\left(\mathbf{1 0}, \mathrm{n}=2-2 \mathrm{PF}_{6}-\mathrm{C}_{29} \mathrm{H}_{41} \mathrm{O}_{10}\left(\text { crownCH}_{2}\right)+\mathrm{H}\right)^{+}\right.$, theory $\left.\mathrm{m} / \mathrm{z} 2159\right] ; \mathrm{m} / \mathrm{z} 3401[(\mathbf{1 7}$, $\left.\mathrm{n}=2-\mathrm{PF}_{6}\right)^{+}$, theory $\mathrm{m} / \mathrm{z}$ 3401]. These initial results demonstrated that the desired building blocks for the hyperbranched system were formed.

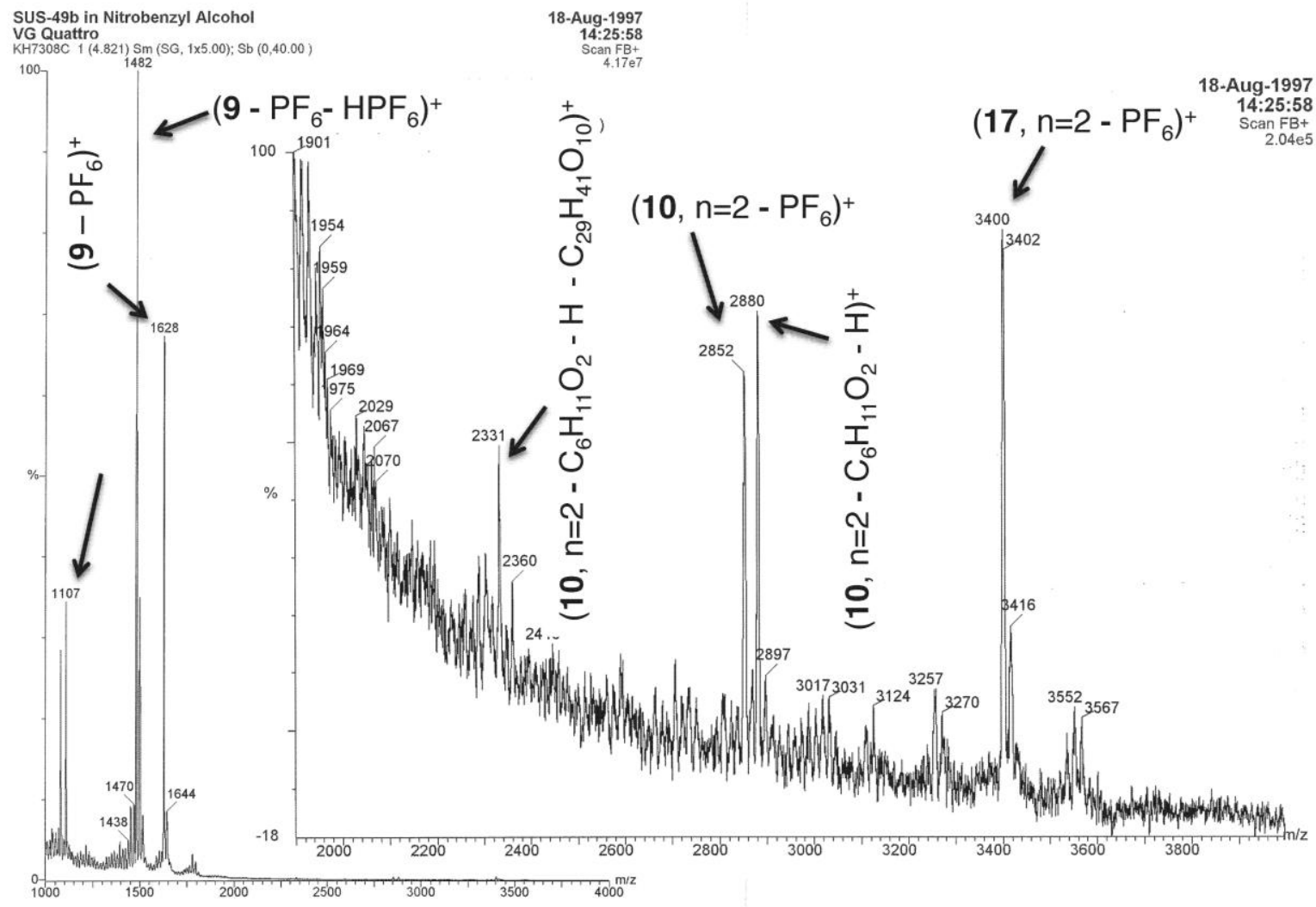

Figure 6. Low resolution FAB mass spectrum of hyperbranched polyester 6 in 3-nitrobenzyl alcohol. The insert for the higher $\mathrm{m} / \mathrm{z}$ values is an expansion of the $\mathrm{y}$-axis by a factor of $\sim 200$. 
Next the LR-FAB-MS (in NBA) of polyester 6 (after precipitation from hot DMSO into aqueous $\mathrm{NH}_{4} \mathrm{PF}_{6}$ ) was examined (Figure 6). The following signals were observed above $\mathrm{m} / \mathrm{z}$ 1000: a base peak at $\mathrm{m} / \mathrm{z} 1482$, corresponding to the simple building block diester $\left[\left(9-\mathrm{PF}_{6}-\right.\right.$ $\left.\mathrm{HPF}_{6}\right)^{+}$, theory $\left.\mathrm{m} / \mathrm{z} 1483\right] ; \mathrm{m} / \mathrm{z} 1628(69 \%)$ assigned to $\left[\left(9-\mathrm{PF}_{6}\right)^{+}\right.$, theory $\left.\mathrm{m} / \mathrm{z} 1628\right]$. Note that the strong peak at $\mathrm{m} / \mathrm{z} 1080$ for $\left[\left(\mathbf{8}-\mathrm{PF}_{6}+\mathrm{H}\right)\right.$ observed in Figure 4 was greatly reduced relative to the $1482 / 1483$ signal; this indicates that precipitation from DMSO removed most of the monoester 8 that was present in semirotaxane units of 5 upon conversion to 6 . Again the $\mathrm{m} / \mathrm{z}$ 1107 signal at the same relative intensity as in Figure 4 is an artifact derived from use of the

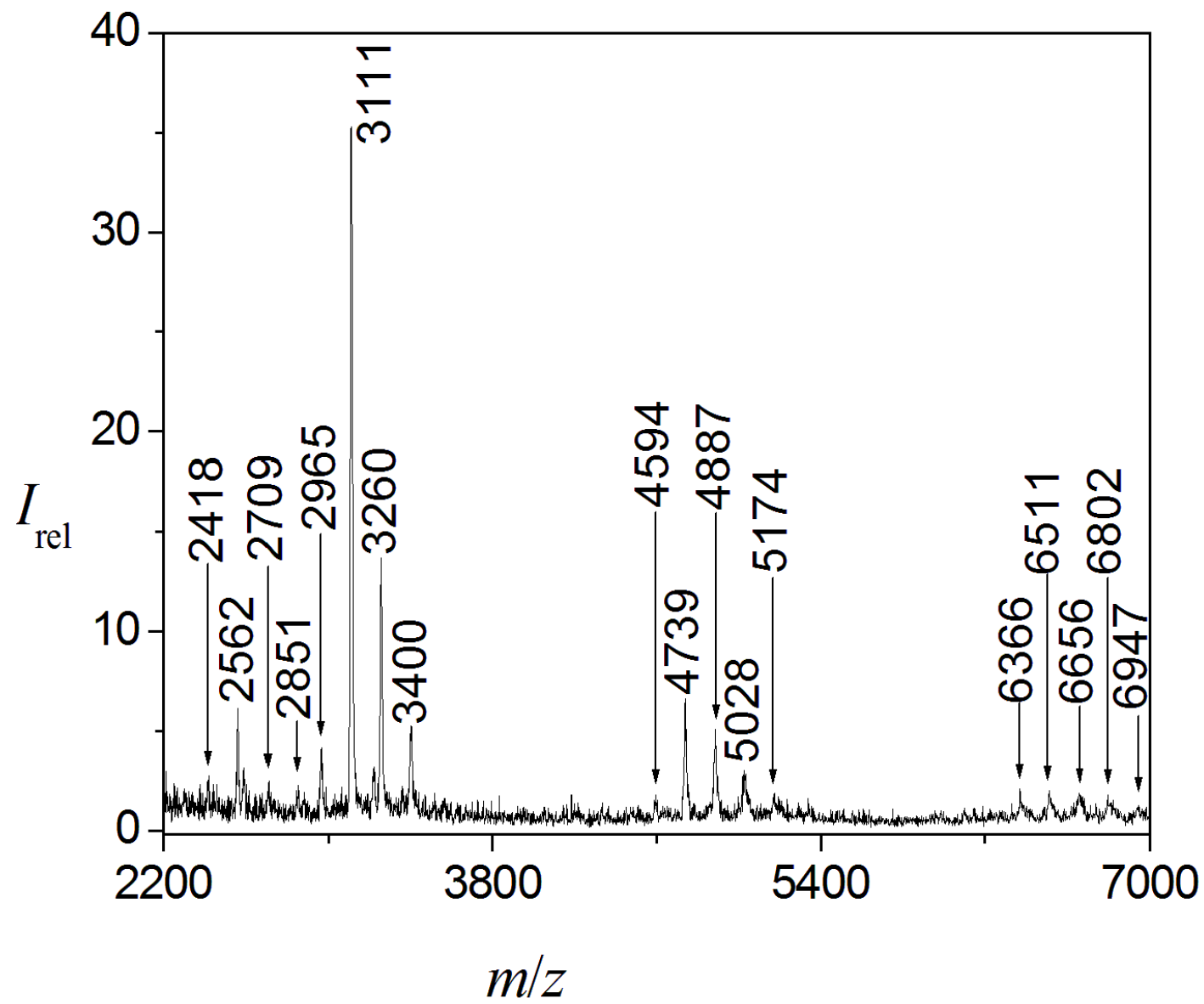

Figure 7. The partial MALDI-TOF mass spectrum of the mechanically interlocked hyperbranched polyester $\mathbf{6}$ in 2,5-dihydroxbenzoic acid. 
instrument to characterize $\mathrm{Sc}_{3} \mathrm{~N} @ \mathrm{C}_{80}$ (exact mass $1109 \mathrm{amu}$ ). ${ }^{26}$ Again weaker signals (0.1 to 0.2 $\%$ ) were observed (in order of decreasing intensity): $\mathrm{m} / \mathrm{z} 3400\left[\left(\mathbf{1 7}, \mathrm{n}=2-\mathrm{PF}_{6}\right)^{+}\right.$, theory $\mathrm{m} / \mathrm{z}$ 23400], $\mathrm{m} / \mathrm{z} 2880\left[\left(\mathbf{1 0}, \mathrm{n}=2-\left(\mathrm{CH}_{2}\right)_{5} \mathrm{COOH}-\mathrm{H}\right)^{+}\right.$, theory $\left.\mathrm{m} / \mathrm{z} 2881\right], \mathrm{m} / \mathrm{z} 2852\left[\left(\mathbf{1 0}, \mathrm{n}=2-\mathrm{PF}_{6}\right)^{+}\right.$, theory $\mathrm{m} / \mathrm{z} 2852]$ and $\mathrm{m} / \mathrm{z} 2331\left[\left(\mathbf{1 0}, \mathrm{n}=2-\left(\mathrm{CH}_{2}\right)_{5} \mathrm{COOH}-\mathrm{H}-\mathrm{C}_{29} \mathrm{H}_{41} \mathrm{O}_{10}\left(\mathrm{crownCH}_{2}\right)\right)^{+}\right.$, theory $\mathrm{m} / \mathrm{z} 2332]$.

The MALDI-TOF mass spectrum taken in 2,5-dihydroxybenzoic acid (Figure 7) provided corroborative support for the formation of the mechanically interlocked hyperbranched polyester $\mathbf{6}$. The strongest peak was found at $m / z 1480(100 \%)$, which corresponds to $\left[\mathbf{9}-2 \mathrm{HPF}_{6}\right.$ $-\mathrm{H}]^{+}$. One more peak was found for $\mathbf{9}: \mathrm{m} / z 1628\left[\mathbf{9}-\mathrm{PF}_{6}\right]^{+}(19 \%)$. Four peaks correspond to $\mathbf{1 0}$, $\mathrm{n}=1: m / z 2851\left[\mathbf{1 0}, \mathrm{n}=1-\mathrm{HPF}_{6}\right]^{+}(2.3 \%), 2709\left[\mathbf{1 0}, \mathrm{n}=1-2 \mathrm{PF}_{6}+2 \mathrm{H}\right]^{+}(2.5 \%), 2562[\mathbf{1 0}, \mathrm{n}=1-$ $\left.3 \mathrm{PF}_{6}\right]^{+}(6.2 \%)$, and $2418\left[\mathbf{1 0}, \mathrm{n}=1-4 \mathrm{PF}_{6}+\mathrm{H}\right]^{+}(2.8 \%)$. Four peaks correspond to 17, $\mathrm{n}=2: \mathrm{m} / \mathrm{z}$ $3400\left[17, \mathrm{n}=2-\mathrm{PF}_{6}\right]^{+}(7.0 \%), 3260\left[\mathbf{1 7}, \mathrm{n}=2-2 \mathrm{HPF}_{6}+\mathrm{Li}\right]^{+}(13 \%), 3111\left[\mathbf{1 7}, \mathrm{n}=2-3 \mathrm{PF}_{6}\right]^{+}$ (40\%), and $2965\left[\mathbf{1 7}, \mathrm{n}=2-4 \mathrm{PF}_{6}\right]^{+}(7.0 \%)$. Five peaks were attributed to $\mathbf{1 7}, \mathrm{n}=3: \mathrm{m} / z 5174[\mathbf{1 7}$, $\left.\mathrm{n}=3-\mathrm{PF}_{6}+\mathrm{H}\right]^{+}(2.0 \%), 5028\left[\mathbf{1 7}, \mathrm{n}=3-2 \mathrm{PF}_{6}\right]^{+}(3.0 \%), 4887\left[17, \mathrm{n}=3-3 \mathrm{HPF}_{6}+\mathrm{Li}\right]^{+}(4.3 \%)$, $4739\left[\mathbf{1 7}, \mathrm{n}=3-4 \mathrm{PF}_{6}+\mathrm{H}\right]^{+}(6.1 \%)$, and $4594\left[\mathbf{1 7}, \mathrm{n}=3-5 \mathrm{PF}_{6}+\mathrm{H}\right]^{+}(2.0 \%)$. Five peaks were due to 17, $\mathrm{n}=4: m / z 6947\left[\mathbf{1 7}, \mathrm{n}=4-\mathrm{PF}_{6}+\mathrm{H}\right]^{+}(1.3 \%), 6802\left[17, \mathrm{n}=4-2 \mathrm{PF}_{6}+\mathrm{H}\right]^{+}(1.8 \%), 6656[17$, $\left.\mathrm{n}=4-3 \mathrm{PF}_{6}\right]^{+}(1.9 \%), 6511\left[\mathbf{1 7}, \mathrm{n}=4-4 \mathrm{PF}_{6}\right]^{+}(2.0 \%)$, and $6366\left[17, \mathrm{n}=4-5 \mathrm{PF}_{6}\right]^{+}(2.1 \%)$. Weaker peaks as high as $m / z 16,305\left[\mathbf{1 7}, \mathrm{n}=11-17 \mathrm{PF}_{6}-5 \mathrm{HPF}_{6}\right]^{+}(0.5 \%)$ corresponding to $\mathbf{1 7}, \mathrm{n}=11$ $(19,499.40-22(144.96)-5(1.01)=16,305.3)$ were observed for hyperbranched polymer 6 (see ESI, Figures S5 and S6); 17, $\mathrm{n}=11$ contains 22 macrocyclic moieties and 11 paraquat units. The successive losses of $\mathrm{PF}_{6}$ anions and $\mathrm{PF}_{6}$ neutrals have been observed previously with paraquat $\mathrm{PF}_{6}$ complexes. ${ }^{18}$ The MALDI-TOF mass spectrum of 6 measured in the positive-ion mode using trans-3-indoleacrylic acid as the matrix gave similar results. Since the MALDI-TOF spectra 
depend on the ability of the molecule to "fly" under the experimental conditions, the possibility of the presence of still larger units in the polymer can not be ruled out. However, the intensity of the peaks diminishes as the molecular weight increases. As with covalent hyperbranched polymers, ${ }^{1,27}$ a broad molecular weight distribution is expected for these mechanically interlocked analogs.

D. Viscosity Study.

Viscous flow is characteristic of polymer solutions. Therefore, we turned to viscometry

(Figure 8) for direct physical evidence of the formation of the mechanically interlocked 28 hyperbranched polymer 6. The relationship between the reduced viscosity of acetone solutions of 6

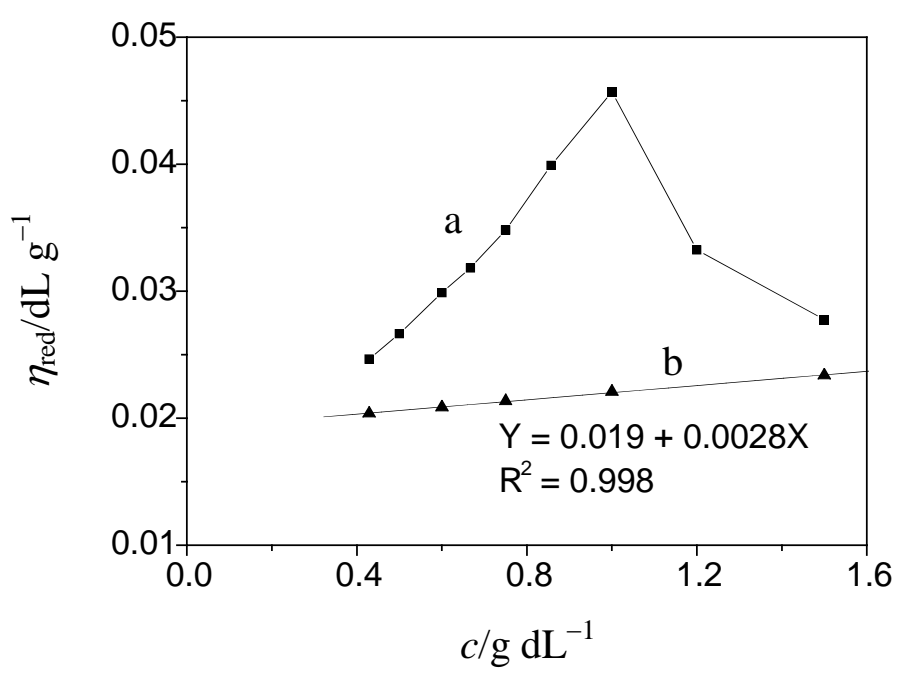

Figure 8. Reduced viscosity of hyperbranched polyester 6 as a function of concentration for solutions in (a) acetone and (b) an acetone solution of $50 \mathrm{mM}$ tetrabutylammonium hexafluorophosphate at $22{ }^{\circ} \mathrm{C}$.

and concentration has the feature typical of traditional covalent polyelectrolytes, that is, a maximum. ${ }^{29,30}$ In order to obtain the intrinsic viscosity, an acetone solution of $50 \mathrm{mM}$ tetrabutylammonium hexafluorophosphate was used as the solvent. The intrinsic viscosity, [ๆ], of 6 in this solution was $0.019 \mathrm{dL} / \mathrm{g} .{ }^{31}$ This low intrinsic viscosity value can be at least partly ascribed to the globular shape of the hyperbranched polymer ${ }^{32}$ and added salt. ${ }^{29}$

\section{Conclusions}

In summary, the first mechanically interlocked hyperbranched polymer $\mathbf{6}$ was successfully prepared (some time ago) from a trifunctional bis( $m$-phenylene)-32-crown-10/paraquat 
pseudorotaxane complex (4). It is a "real" mechanically interlocked dendritic polymer because all of its generations are connected by non-convalent interactions. ${ }^{33}$ The polymer consists of macrocycles as the peripheral groups with the promising possibility of a large number of peripheral host units for molecular recognition. This facile method for preparing threedimensional interlocked dendritic macromolecules can be expanded to prepare other dendritic interlocked macromolecules and similar interlocked macromolecules based on other wellestablished recognition motifs. The present results provide proof of principle for a method of construction of mechanically linked hyperbranched systems. To achieve higher molecular weight requires design/syntheses of host-guest systems with stronger complexation. We have recently

reported such systems with greatly enhanced association constants,${ }^{34}$ which can be used for this purpose.

\section{Experimental Section}

General. All solvents were HPLC or GC grade. NMR solvents were bought from Cambridge Isotope Laboratories and used as received. The NMR spectra were recorded on Varian Unity or Inova $400 \mathrm{MHz}$ instruments. The melting points were taken in capillary tubes and are uncorrected. Elemental analyses were performed by Atlantic Microlabs of Norcross, GA. Viscosities were measured with a Cannon-Ubbelohde semi-micro dilution viscometer with 200 centipoise inner diameter capillary. LR FAB mass spectrometric measurements were done in house on a Fisons VG Quattro instrument. MALDI-TOF mass spectrometry was carried out at the Washington University Resource for Biomedical and Bio-organic Mass Spectrometry employing an Applied Biosystems Voyager system. 
N,N'-Bis(5"-carboxypentyl)-4,4'-bipyridinium Bis(hexafluorophosphate) (1). 4,4'-Dipyridyl

$(2.86 \mathrm{~g}, 18.3 \mathrm{mmol})$ in $20 \mathrm{~mL}$ acetonitrile was added slowly to a refluxing solution of 6 bromohexanoic acid $(24.98 \mathrm{~g}, 128.1 \mathrm{mmol})$ in $20 \mathrm{~mL}$ acetonitrile over a period of $20 \mathrm{~h}$ under nitrogen. Heating under reflux was continued for $10 \mathrm{~h}$. The yellow precipitate was filtered and washed several times with acetonitrile. The resulting solid was dissolved in water (readily soluble). The aqueous solution was poured into a saturated solution of $\mathrm{NH}_{4} \mathrm{PF}_{6}$. The resultant precipitate was filtered and washed several times with water and dried under vacuum at $50{ }^{\circ} \mathrm{C}$ for $24 \mathrm{~h}$ to yield 1 as a colorless solid (7.86 g, 63\%), mp 186.5-188.3 ${ }^{\circ} \mathrm{C} .{ }^{1} \mathrm{H}$ NMR (400 MHz, acetone- $\left.d_{6}, 22{ }^{\circ} \mathrm{C}\right): \delta=1.48-1.55(\mathrm{~m}, 4 \mathrm{H}), 1.63-1.71(\mathrm{~m}, 4 \mathrm{H}), 2.18-2.26(\mathrm{~m}, 4 \mathrm{H}), 2.31(\mathrm{t}, J=7$ Hz, 4H), $4.97(\mathrm{t}, J=7 \mathrm{~Hz}, 4 \mathrm{H}), 8.84(\mathrm{~d}, J=7 \mathrm{~Hz}, 4 \mathrm{H}), 9.46(\mathrm{~d}, J=7 \mathrm{~Hz}, 4 \mathrm{H}), 10.52$ (brs, $1 \mathrm{H})$. ${ }^{13} \mathrm{C}$ NMR $\left(400 \mathrm{MHz}\right.$, acetone- $\left.d_{6}, 22{ }^{\circ} \mathrm{C}\right): \delta=23.88,25.21,30.91,32.86,61.96,127.26,146.00$, 150.07, 173.66. Anal. calcd for $\mathrm{C}_{22} \mathrm{H}_{30} \mathrm{O}_{4} \mathrm{~N}_{2} \mathrm{P}_{2} \mathrm{~F}_{12}$ : C, 39.06; H, 4.47; found : C, 39.00; H, 4.48.

N,N'-Bis(5"-benzyloxycarbonylpentyl)-4,4'-bipyridinium Bis(hexafluorophosphate) (7). In a three necked $50 \mathrm{~mL}$ round-bottom flask, equipped with a reflux condenser, nitrogen inlet and stoppers, N,N'-bis(5"-carboxypentyl)-4,4'-bipyridinium bis(hexafluorophosphate) (1, $0.115 \mathrm{~g}$, $0.17 \mathrm{mmol}$ ) was refluxed in $3 \mathrm{~mL}$ of $\mathrm{SOCl}_{2}$ for $2 \mathrm{~h}$. The excess thionyl chloride was removed under vacuum and the system was flushed with nitrogen. Dry acetonitrile $(2 \mathrm{~mL}$, freshly distilled from $\mathrm{CaH}_{2}$ and collected over molecular sieves) was added; the acid chloride dissolved. Benzyl alcohol $(0.035 \mathrm{~mL}, 0.34 \mathrm{mmol})$ and $0.027 \mathrm{~mL}(0.34 \mathrm{mmol})$ of pyridine were added. The mixture was stirred at room temperature for $24 \mathrm{~h}$ and poured into water. The solid was filtered, washed several times with water and dried, $0.132 \mathrm{~g}(91 \%), \mathrm{mp} 239.5$ - $247.6{ }^{\circ} \mathrm{C}(\mathrm{dec}) .{ }^{1} \mathrm{H}$ NMR (acetone$\left.\mathrm{d}_{6}\right): \delta(\mathrm{ppm}) 1.50-1.56(\mathrm{~m}, 4 \mathrm{H}), 1.70-1.74(\mathrm{~m}, 4 \mathrm{H}), 2.21-2.26(\mathrm{~m}, 4 \mathrm{H}), 2.40(\mathrm{t}, J=7,4 \mathrm{H}), 4.97(\mathrm{t}$, 
$J=7,4 \mathrm{H}), 5.10(\mathrm{~s}, 4 \mathrm{H}), 7.34-7.37(\mathrm{~m}, 10 \mathrm{H}), 8.84(\mathrm{~d}, J=6,4 \mathrm{H}), 9.46(\mathrm{~d}, J=6)$. Anal., calcd for $\mathrm{C}_{36} \mathrm{H}_{42} \mathrm{O}_{4} \mathrm{~N}_{2} \mathrm{P}_{2} \mathrm{~F}_{12}$ : C 50.47; $\mathrm{H}$ 4.94; found: C 50.45; $\mathrm{H} 4.92$.

Measurements of Association Constants for 1@3 and 7@3. Exchange is fast on the NMR time scale. Thus, a series of titrations were performed. A specified concentration of the guest paraquat 1 or $\mathbf{7}$ in acetone was prepared in a volumetric flask. A small and exact volume of this solution was added to an NMR tube using a to-deliver pipet; the remainder was used to prepare a known concentration of host 3 . $^{20}$ Titration was achieved by adding a defined volume of this paraquat guest plus host solution to the NMR tube with a to-deliver pipet. Thus, the initial component concentrations were known while the total guest concentration remained constant. Upon mixing, charge transfer yielded an orange solution, indicative of the rapid formation of a [2]pseudorotaxane via through-space $\pi$-stacking interactions of host and guest. The ${ }^{1} \mathrm{H}$ NMR data (Tables 1 and 4) were collected on a temperature controlled $\left( \pm 0.1{ }^{\circ} \mathrm{C}\right)$ spectrometer. The data were analyzed using the iterative Cresswell-Allred method (Tables 2 and 5). ${ }^{18 f, 19}$ A van't Hoff plot was used to determine the thermodynamic parameters shown in Table 3.

Table 1. Temperature Dependence of the Chemical Shifts (400 MHz, acetone- $\mathrm{d}_{6}$ ) of Protons $\mathrm{H}_{6}$ and $\mathrm{H}_{7}$ of $\mathbf{1}$ Upon Complexation with 3 . $^{\mathrm{a}}$

\begin{tabular}{|c|c|c|c|c|c|}
\hline $\begin{array}{c}{[3]_{\mathrm{o}}} \\
(\mathrm{mM})\end{array}$ & $\begin{array}{c}21.4{ }^{\circ} \mathrm{C} \\
\delta_{6} / \delta_{7}{ }^{\mathrm{b}} \\
(\mathrm{ppm})\end{array}$ & $\begin{array}{c}30.0{ }^{\circ} \mathrm{C} \\
\delta_{6} / \delta_{7}{ }^{\mathrm{b}} \\
(\mathrm{ppm})\end{array}$ & $\begin{array}{c}38.0{ }^{\circ} \mathrm{C} \\
\delta_{6} / \delta_{7}{ }^{\mathrm{b}} \\
(\mathrm{ppm})\end{array}$ & $\begin{array}{c}46.0{ }^{\circ} \mathrm{C} \\
\delta_{6} / \delta_{7}{ }^{\mathrm{b}} \\
(\mathrm{ppm})\end{array}$ & $\begin{array}{c}54.0{ }^{\circ} \mathrm{C} \\
\delta_{6} / \delta_{7}{ }^{\mathrm{b}} \\
(\mathrm{ppm})\end{array}$ \\
\hline 0.00 & $9.492 / 8.867$ & $9.484 / 8.860$ & $9.476 / 8.851$ & $9.469 / 8.844$ & $9.462 / 8.836$ \\
\hline 3.51 & $9.406 / 8.687$ & $9.413 / 8.709$ & $9.419 / 8.730$ & $9.423 / 8.747$ & $9.426 / 8.761$ \\
\hline 6.92 & $9.353 / 8.571$ & $9.369 / 8.611$ & $9.383 / 8.648$ & $9.394 / 8.681$ & $9.402 / 8.708$ \\
\hline 10.43 & $9.317 / 8.494$ & $9.337 / 8.541$ & $9.356 / 8.586$ & $9.371 / 8.627$ & $9.383 / 8.664$ \\
\hline 13.90 & $9.295 / 8.448$ & $9.315 / 8.493$ & $9.335 / 8.539$ & $9.352 / 8.585$ & $9.367 / 8.627$ \\
\hline 17.47 & $9.283 / 8.420$ & $9.301 / 8.461$ & $9.320 / 8.506$ & $9.339 / 8.554$ & $9.355 / 8.598$ \\
\hline 20.68 & $9.273 / 8.400$ & $9.290 / 8.433$ & $9.308 / 8.479$ & $9.327 / 8.527$ & $9.343 / 8.572$ \\
\hline 27.42 & $9.261 / 8.375$ & $9.275 / 8.405$ & $9.292 / 8.444$ & $9.310 / 8.489$ & $9.326 / 8.535$ \\
\hline
\end{tabular}

${ }^{\mathrm{a}}[\mathbf{1}]_{\mathrm{o}}$ held constant at $6.889 \mathrm{mM}$. ${ }^{\mathrm{b}}$ Chemical shift $\pm 0.001 \mathrm{ppm}$. 
Table 2. Temperature Dependence of Association Constant for $1 @ 3$ Determined via Iterative Cresswell-Allred Treatment.

\begin{tabular}{|c|c|c|c|c|c|}
\hline Obs. Proton & $\begin{array}{c}\text { Temperature } \\
\left({ }^{\mathrm{C}} \mathrm{C}\right)\end{array}$ & $\begin{array}{c}\Delta_{\mathrm{o}} \\
(\mathrm{ppm})\end{array}$ & $\begin{array}{c}\mathrm{K}_{\mathrm{a}} \\
\left(\mathrm{M}^{-1}\right)\end{array}$ & $\mathrm{r}^{2}$ & $\delta_{\text {int }} / \delta_{\text {free }}{ }^{\mathrm{a}}$ \\
\hline $\mathrm{H}_{6}$ & 21.4 & 0.256 & $398 \pm 19$ & 0.999 & 0.999990 \\
$\mathrm{H}_{7}$ & & 0.552 & $369 \pm 10$ & 1.000 & 0.999983 \\
\hline $\mathrm{H}_{6}$ & 30.0 & 0.244 & $254 \pm 11$ & 0.999 & 0.999998 \\
$\mathrm{H}_{7}$ & & 0.544 & $230 \pm 6$ & 0.999 & 0.999983 \\
\hline $\mathrm{H}_{6}$ & 38.0 & 0.231 & $167 \pm 7$ & 0.998 & 0.999988 \\
$\mathrm{H}_{7}$ & & 0.523 & $148 \pm 3$ & 1.000 & 0.999970 \\
\hline $\mathrm{H}_{6}$ & 46.0 & 0.212 & $125 \pm 5$ & 0.997 & 0.999988 \\
$\mathrm{H}_{7}$ & & 0.500 & $104 \pm 2$ & 0.999 & 0.999992 \\
\hline $\mathrm{H}_{6}$ & 54.0 & 0.198 & $88 \pm 4$ & 0.997 & 0.999996 \\
$\mathrm{H}_{7}$ & & 0.474 & $74 \pm 2$ & 0.999 & 0.999966 \\
\hline
\end{tabular}

a This parameter compares the intercept of the plot of observed chemical shifts vs. the iteratively calculated $\Delta_{\mathrm{o}}$ [3]/[1] to the measured value for the free guest; the number of nines represents the degree of convergence in the determination of $\mathrm{K}_{\mathrm{a}}$ and $\Delta_{\mathrm{o}}$.

Table 3. Thermodynamic Parameters Determined for the Complexation of $\mathbf{1}$ and $\mathbf{3}$ from a van't Hoff Plot of the Temperature Dependent Association Constant.

\begin{tabular}{|c|c|c|c|c|c|}
\hline Obs. Proton & $\begin{array}{c}\text { Slope } \\
(\mathrm{K})\end{array}$ & Intercept & $\mathrm{r}^{2}$ & $\begin{array}{c}\Delta \mathrm{H} \\
(\mathrm{kcal} / \mathrm{mol})\end{array}$ & $\begin{array}{c}\Delta \mathrm{S} \\
(\mathrm{eu})\end{array}$ \\
\hline $\mathrm{H}_{6}$ & 4438 & -9.096 & 0.998 & $-8.82 \pm 0.19$ & $-18.1 \pm 0.2$ \\
\hline $\mathrm{H}_{7}$ & 4771 & -10.30 & 0.999 & $-9.48 \pm 0.20^{\mathrm{a}}$ & $-20.5 \pm 0.5^{\mathrm{a}}$ \\
\hline
\end{tabular}

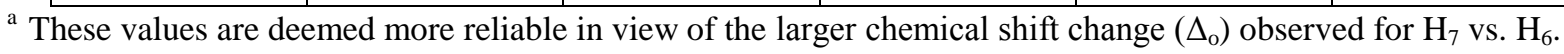


Table 4. Chemical Shifts (400 MHz, acetone- $\mathrm{d}_{6}$ ) of Protons $\mathrm{H}_{6}$ and $\mathrm{H}_{7}$ of 7 Upon Complexation with $\mathbf{3}$ at $21.4{ }^{\circ} \mathrm{C}$.

\begin{tabular}{|c|c|c|}
\hline $\begin{array}{c}{[3]_{\mathrm{o}}} \\
(\mathrm{mM})\end{array}$ & $\begin{array}{c}\delta_{6}{ }^{\mathrm{b}} \\
(\mathrm{ppm})\end{array}$ & $\begin{array}{c}\boldsymbol{\delta}_{7}{ }^{\mathrm{b}} \\
(\mathrm{ppm})\end{array}$ \\
\hline 0.00 & 9.470 & 8.849 \\
\hline 2.10 & 9.410 & 8.720 \\
\hline 3.80 & 9.370 & 8.632 \\
\hline 10.3 & 9.294 & 8.465 \\
\hline 13.4 & 9.278 & 8.433 \\
\hline 17.7 & 9.263 & 8.400 \\
\hline 21.5 & 9.257 & 8.385 \\
\hline 28.12 & 9.246 & 8.362 \\
\hline 42.5 & 9.233 & 8.340 \\
\hline
\end{tabular}

${ }^{\mathrm{a}}[7]_{\mathrm{o}}$ held constant at $5.190 \mathrm{mM} .{ }^{\mathrm{b}}$ Chemical shift $\pm 0.001 \mathrm{ppm}$.

Table 5. Association Constant for $7 @ 3$ Determined via Iterative Cresswell-Allred Treatment.

\begin{tabular}{|c|c|c|c|c|}
\hline Obs. Proton & $\begin{array}{c}\Delta_{\mathrm{o}} \\
(\mathrm{ppm})\end{array}$ & $\begin{array}{c}\mathrm{K}_{\mathrm{a}} \\
\left(\mathrm{M}^{-1}\right)\end{array}$ & $\mathrm{r}^{2}$ & $\delta_{\text {int }} / \delta_{\text {free }}{ }^{\mathrm{a}}$ \\
\hline $\mathrm{H}_{6}$ & 0.248 & $386 \pm 39$ & 0.999 & 0.999995 \\
\hline $\mathrm{H}_{7}$ & 0.540 & $379 \pm 18$ & 0.999 & 0.999996 \\
\hline
\end{tabular}

a This parameter compares the intercept of the plot of observed chemical shifts vs. the iteratively calculated $\Delta_{\mathrm{o}}$ [3]/[7] to the measured value for the free guest; the number of nines represents the degree of convergence in the determination of $\mathrm{K}_{\mathrm{a}}$ and $\Delta_{\mathrm{o}}$.

Topologically Hyperbranched Polyester Rotaxane (5b and 6). In a three-necked $50 \mathrm{~mL}$ round-bottom flask, equipped with a reflux condenser, magnetic stirrer, and nitrogen inlet, paraquat diacid $1(0.3382 \mathrm{~g}, 0.5001 \mathrm{mmol})$ was refluxed in $5 \mathrm{~mL}$ of $\mathrm{SOCl}_{2}$ for $2 \mathrm{~h}$. The excess thionyl chloride was removed under vacuum and the system was flushed with nitrogen. Dry acetonitrile $\left(2.0 \mathrm{~mL}\right.$, freshly distilled from $\mathrm{CaH}_{2}$ and collected over molecular sieves) was added to the flask along with crown ether alcohol $3^{20}(0.280 \mathrm{~g}, 0.494 \mathrm{mmol})$ and the temperature of the resulting solution was immediately lowered to $-70{ }^{\circ} \mathrm{C}$ in a dry ice-acetone bath. The solution was intense yellow-orange in color. The temperature was slowly raised to $-15^{\circ} \mathrm{C}$ by the removal of the bath and pyridine $(0.8 \mathrm{~mL})$ was added; there was no change in color, but the viscosity began to increase. The mixture was then allowed to warm and stirred at room temperature for 8 
days. Acetonitrile $(6 \mathrm{~mL})$ was added to aid in stirring of the viscous mixture for another 4 days. The reaction mixture was poured into a saturated aqueous solution of $\mathrm{NH}_{4} \mathrm{PF}_{6}$. An intense yellow gum-like material $(0.59 \mathrm{~g}, 95 \%)$ separated out. It was filtered, dried and dissolved in acetonitrile and precipitated into a dilute aqueous $\mathrm{NH}_{4} \mathrm{PF}_{6}$ solution. The product was reprecipitated five more times in this way (5b). A part of the precipitate was dissolved in hot DMSO and precipitated into a hot aq $\mathrm{NH}_{4} \mathrm{PF}_{6}$ solution. Two more reprecipitations were carried out in this manner and the final product (6) was dried under vacuum at room temperature for $48 \mathrm{~h}$.

\section{ACKNOWLEDGMENT}

This work was supported by the National Science Foundation (DMR0097126) and the Petroleum Reasearch Fund (40223-AC7). We thank Mr. Kim Harich of Virginia Tech for providing the FAB mass spectra. MALDI-TOF mass spectra were provided by the Washington University Resource for Biomedical and Bio-organic Mass Spectrometry (NIH P41RR0954).

Keywords: host-guest systems, self-assembly, crown ether, interlocked macromolecule, paraquat

\section{REFERENCES}

1. (a) Tomalia, D. A.; Naylor, A. M.; Goddard, W. A., III. Angew. Chem. 1990, 102, 119157 ;

b) Moorefield, C. N.; Newkome, G. R. Adv. Dendritic Macromol. 1994, 1, 1-67;

c) Fréchet, J. M. J.; Hawker, C. J.; Wooley, K. L. J. Macromol. Sci., Pure Appl. Chem. 1994, A31, 1627-45;

d) Bosman, A. W.; Janssen, H. M.; Meijer, E. W. Chem. Rev. 1999, 99, 1665-1688;

e) Newkome, G. R.; He, E.; Moorefield, C. N. Chem. Rev. 1999, 99, 1689-1746;

f) Grayson, S. M.; Fréchet, J. M. J. Chem. Rev. 2001, 101, 3819-3867; 
g) Dendrimers and Other Dendritic Polymers; Fréchet, J. M. J.; Tomalia, D. A. Eds.; J. Wiley and Sons: New York, 2001.

h) Tomalia, D. A.; Fréchet, J. M. J. J. Polym. Sci., Part A: Polym. Chem. 2002, 40, 27192728

i) Gao, C.; Yan, D. Prog. Polym. Sci. 2004, 29, 183-275;

j) Fréchet, J. M. J. J. Polym. Sci., Part A: Polym. Chem. 2003, 41, 3713-3725;

k) Yates, C. R.; Hayes, W. Eur. Polym. J. 2004, 40, 1257-1281;

l) Advances in Dendritic Macromolecules; Newkome, G. R. Ed.; JAI Press, Inc.: Stamford, CN, continuing series, 1996-.

m) Chem. Soc. Rev. 2015, 44, issue 12.

2. (a) Helms, B.; Fréchet, J. M. J. Adv. Syn. Catal. 2006, 348, 1125-1148;

b) Andrews, D. L. J. Mater. Res. 2012, 27, 627-638;

c) Deraedt, C.; Astruc, D. Acc. Chem. Res. 2014, 47, 494-503;

d) Caminade, A.-M.; Ouali, A.; Laurent, R.; Majoral, J.-P. Inorg. Chim. Acta 2015, 431, 3-20;

e) Mignani, S.; Bryszewska, M.; Klajnert-Maculewicz, B.; Zablocka, M.; Majoral, J.-P. Biomacromol. 2015, 16, 1-27;

f) Yang, J.; Zhang, Q.; Chang, H.; Cheng, Y. Chem. Rev. 2015, 115, 5274-5300;

g) Leiro, V.; Garcia, J. P.; Tomas, H.; Pego, A. P. Bioconj. Chem. 2015, 26, 1182-1197.

3. a) Teertstra, S. J.; Gauthier, M. Progr. Polym. Sci. 2004, 29, 277-327;

b) Sanchez C. L.-E.; Gauthier, M. Polymers 2010, 2, 596-622.

4. a) Hong, Y.; Coombs, S. J.; Cooper-White, J. J.; Mackay, M. E.; Hawker, C. J.; Malmstrom, E.; Rehnberg, N. Polymer 2000, 41, 7705-7713; 
b) Ratna, D.; Varley, R.; Simon, G. P. J. Appl. Polym. Sci. 2004, 92, 1604-1610.

5. a) Varley, R. J. Polym. Int. 2004, 53, 78-84;

b) Karger-Kocsis, J.; Frohlich, J.; Gryshchuk, O.; Kautz, H.; Frey, H.; Mulhaupt, R. Polymer 2004, 45, 1185-1195.

6. a) Gao, C.; Xu, Y.; Yan, D.; Chen, W. Biomacromolecules 2003, 4, 704-12;

b) Kolhe, P.; Misra, E.; Kannan, R. M.; Kannan, S.; Lieh-Lai, M. Int. J. Pharm. 2003, 259, 143-160.

7. a) Kantchev, A. B.; Parquette, J. R. Tetrahedron Lett. 1999, 40, 8049-8053;

b) Haag, R. Chem. Eur. J. 2001, 7, 327-335.

8. $\quad$ a) Tao, X. T.; Zhang, Y. D.; Wada, T.; Sasabe, H.; Suzuki, H.; Watanabe, T.; Miyata, S. Adv. Mater. 1998, 10, 226-230;

b) Zhao, M.; Liu, Y.; Crooks, R. M.; Bergbreiter, D. E. J. Am. Chem. Soc. 1999, 121, 923-930.

9. a) Takeuchi, M.; Jikei, M.; Kakimoto, M.-A. High Perform. Polym. 2003, 15, 219-228;

b) Hong, L.; Shi, L.; Tang, X. Macromolecules 2003, 36, 4989-4994.

10. Pitois, C.; Wiesmann, D.; Lindgren, M.; Hult, A. Adv. Mater. 2001, 13, 1483-1487.

11. a) Gibson, H. W.; Yamaguchi, N.; Hamilton, L.; Jones, J. W. J. Am. Chem. Soc. 2002, 124, 4653-4665;

b) Ma, Y.; Kolotuchin, S. V.; Zimmerman, S. C. J. Am. Chem. Soc. 2002, 124, 1375713769;

c) Elizarov, A. M.; Chiu, S.-H.; Glink, P. T.; Stoddart, J. F. Org. Lett. 2002, 4, 679-682;

d) Elizarov, A. M.; Chang, T.; Chiu, S.-H.; Stoddart, J. F. Org. Lett. 2002, 4, 3565-3568;

e) Jeong, K.-S.; Park, E.-J. J. Org. Chem. 2004, 69, 2618-2621. 
12. Li, S.; Zheng, B.; Chen, J.; Dong, S.; Ma, Z.; Huang, F.; Gibson, H. W. J. Polym. Sci., Polym. Chem. 2010, 48, 4067-4073.

13. Huck, W. T. S.; Van Veggel, F. C. J. M.; Reinhoudt, D. N. J. Mater. Chem. 1997, 7, 1213-1219.

14. a) Noll, O.; Ritter, H. Macromol. Chem. Phys. 1998, 199, 791-794;

b) Gong, C.; Ji, Q.; Subramaniam, C.; Gibson, H. W. Macromolecules 1998, 31, 18141818.

c) Gong, C.; Balanda, P. B.; Gibson, H. W. Macromolecules 1998, 31, 5278-5289;

d) Zhao, T.; Beckham, H. W.; Gibson, H. W. Macromolecules 2003, 36, 4833-4837;

e) Kidd, T. J.; Loontjens, T. J. A.; Leigh, D. A.; Wong, J. K. Y. Angew. Chem. Int. Ed. 2003, 42, 3379-3383;

f) Werts, M. P. L.; van den Boogaard, M.; Tsivgoulis, G. M.; Hadziioannou, G. Macromolecules 2003, 36, 7004-7013;

g) Oku, T.; Furusho, Y.; Takata, T. Angew. Chem. Int. Ed. 2004, 43, 966-969;

h) Karino, T.; Okumura, Y.; Ito, K.; Shibayama, M. Macromolecules 2004, 37, 61776182;

i) Choi, H. S.; Ooya, T.; Lee, S. C.; Sasaki, S.; Kurisawa, M.; Uyama, H.; Yui, N. Macromolecules 2004, 37, 6705-6710;

j) Okada, M.; Harada, A. Org. Lett. 2004, 6, 361-364;

k) Tuncel, D.; Steinke, J. H. G. Macromolecules 2004, 37, 288-302;

1) Arunachalam, M.; Gibson, H. W. Progr. Polym. Sci., 2014, 39, 1043-1073.

15. a) Hamers, C.; Raymo, F. M.; Stoddart, J. F. Eur. J. Org. Chem. 1998, 2109-2117; 
b) Weidmann, J.-L.; Kern, J.-M.; Sauvage, J.-P.; Muscat, D.; Mullins, S.; Köhler, W.; Rosenauer, C.; Räder, H. J.; Martin, K.; Geerts, Y. Chem. Eur. J. 1999, 5, 1841-1851;

c) Raymo, F. M.; Stoddart, J. F. Supramol. Polym. 2000, 323-357;

d) Fustin, C. A.; Clarkson, G. J.; Leigh, D. A.; Van Hoof, F.; Jonas, A. M.; Bailly, C. Macromolecules 2004, 37, 7884-7892;

e) Endo, K.; Shiroi, T.; Murata, N.; Kojima, G.; Yamanaka, T. Macromolecules 2004, 37, 3143-3150;

f) Watanabe, N.; Ikari, Y.; Kihara, N.; Takata, T. Macromolecules 2004, 37, 6663-6666;

g) Godt, A. Eur. J. Org. Chem. 2004, 1639-1654;

h) Gibson, H. W.; Nagvekar, D. S.; Yamaguchi, N.; Bhattacharjee, S.; Wang, H.; Vergne, M. J.; Hercules, D. M. Macromolecules, 2004, 37, 7514-7529;

i) Niu, Z.; Gibson, H. W. Chem. Rev. 2009, 109, 6024-6046.

16. a) Gong, C.; Gibson, H. W. Curr. Opin. Solid St. Mater. Sci. 1997, 2, 647-652;

b) Raymo, F. M.; Stoddart, J. F. Chem. Rev. 1999, 99, 1643-1663;

c) Catenanes, Rotaxanes and Knots; Sauvage, J.-P.; Dietrich-Buchecker, C. O. Eds.; Wiley-VCH: Weinheim, 1999;

d) Mahan, E.; Gibson, H. W. In Cyclic Polymers, 2nd ed.; Semlyen, J. A. Ed.; Kluwer Publishers: Dordrecht, 2000; pp 415-560;

e) Kim, K. Chem. Soc. Rev. 2002, 31, 96-107;

f) Carlucci, L.; Ciani, G.; Proserpio, D. M. Coordin. Chem. Rev. 2003, 246, 247-289.

17. Dr. Bhattacharjee recorded her first experiment on February 21, 1997.

18. a) Allwood, B. L.; Spencer, N.; Shahriari-Zavareh, H.; Stoddart, J. F.; Williams, D. J. Chem. Commun. 1987, 1058-1061; 
b) Shen, Y. X.; Engen P. T.; Berg, M. A. G.; Merola, J. S.; Gibson, H. W. Macromolecules 1992, 25, 2786-2788;

c) Delaviz, Y.; Merola, J. S.; Berg, M. A. G.; Gibson, H. W. J. Org. Chem. 1995, 60, 516522

d) Gong, C.; Gibson, H. W. Macromol. Chem. Phys. 1998, 199, 1801-1806;

e) Yamaguchi, N.; Nagvekar, D. and Gibson, H. W. Angew. Chem. Int. Ed. Engl. 1998, 38, 2361-2364;

f) Gong, C.; Balanda, P. B.; Gibson, H. W. Macromolecules 1998, 31, 5278-5289;

g) Bryant, W. S.; Jones, J. W.; Mason, P. E.; Guzei, I. A.; Rheingold, A. L.; Nagvekar, D.

S.; Gibson, H. W. Org. Lett. 1999, 1, 1001-1004;

h) Jones, J. W.; Zakharov, L. N.; Rheingold, A. L.; Gibson, H. W. J. Am. Chem. Soc. 2002, 124, 13378-13379;

i) Jones, J. W.; Bryant, W. S.; Bosman, A. W.; Janssen, R. A. J.; Meijer, E. W.; Gibson, H. W. J. Org. Chem. 2003, 68, 2385-2389;

j) Huang, F.; Fronczek, F. R.; Gibson, H. W. Chem. Commun. 2003, 1480-1481;

k) Huang, F.; Jones, J. W.; Gibson, H. W. J. Am. Chem. Soc. 2003, 125, 14458-14464;

1) Huang, F.; Nagvekar, D. S.; Slebodnick, C.; Gibson, H. W. J. Am. Chem. Soc. 2005, 127, 484-485;

m) Huang, F.; Guzei, I. A.; Jones, J. W.; Gibson, H. W. Chem. Commun. 2005, 1693 1695

n) Gibson, H. W.; Ge, Z.; Huang, F.; Jones, J. W.; Lefebvre, H.; Vergne, M. J.; Hercules, D. M. Macromolecules 2005, 38, 2626-2637; 
o) Huang, F.; Zakharov, L. N.; Bryant, W. S.; Rheingold, A. L.; Gibson, H. W. Chem. Commun. 2005, 3268-3270;

p) Huang, F.; Gantzel, P.; Nagvekar, D. S.; Rheingold, A. L.; Gibson, H. W. Tetrahedron Lett. 2006, 47, 7841-7844;

q) Huang, F.; Nagvekar, D. S.; Zhou, X. C.; Gibson, H. W. Macromolecules 2007, 40, 3561-3567;

r) Zhang, J.; Zhai, C.; Wang, F.; Zhang, C.; Li, S.; Zhang, M.; Li, N.; Huang, F. Tetrahedron Lett. 2008, 49, 5009-5012;

s) Zhu, K.; He, J.; Li, S.; Liu, M.; Wang, F.; Zhang, M.; Abliz, Z.; Yang, H.; Li, N.; Huang, F. J. Org. Chem. 2009, 74, 3905-3912;

t) Li, S.; Zhu, K.; Zheng, B.; Wen, X.; Li, N.; Huang, F. Eur. J. Org. Chem. 2009, 10531057

u) Gibson, H. W.; Farcas, A.; Jones, J. W.; Ge, Z.; Huang, F.; Vergne, M.; Hercules, D. M. J. Polym. Sci., Polym. Chem. Ed. 2009, 47, 3518-3543;

v) Zhu, K.; Li, S.; Wang, F.; Huang, F. J. Org. Chem. 2009, 74, 1322-1328;

w) Lee, M.; Schoonover, D.; Gies, A.; Hercules, D. M.; Gibson, H. W. Macromolecules 2009, 42, 6483-6494;

x) Zhang, M.; Luo, Y.; Zheng, B.; Yan, X.; Fronczek, F. R.; Huang, F. Eur. J. Org. Chem. 2010, 35, 6798-6803;

y) Niu, Z.; Slebodnick, C.; Bonrad, K.; Huang, F.; Gibson, H. W. Org. Lett. 2011, 13, 2872-2875;

z) Niu, Z.; Slebodnick, C.; Schoonover, D. V.; Azurmendi, H.; Harich, K.; Gibson, H. W. Org. Lett. 2011, 13, 3992-3995; 
aa) Lee, M.; Moore, R. B.; Gibson, H. W. Macromolecules 2011, 44, 5987-5993;

bb) Niu, Z.; Slebodnick, C.; Gibson, H. W. Org. Lett. 2011, 13, 4616-4619;

cc) Niu, Z.; Slebodnick, C.; Huang, F.; Azurmendi, H.; Gibson, H. W. Tetrahedron Lett. 2011, 52, 6379-6382.

19. Cresswell, C. G.; Allred, A. L. J. Phys. Chem. 1962, 66, 1469.

20. Gibson, H. W.; Nagvekar, D. S.; Yamaguchi, N.; Wang, F.; Bryant, W. S. J. Org. Chem. 1997, 62, 4798-4803.

21. For $1 \bullet 3, K_{\mathrm{a}}=5.4 \times 10^{6} \mathrm{M}^{-1}$ at $-70^{\circ} \mathrm{C}$. Therefore, ca. $0.1 \%$ would remain uncomplexed under these conditions.

22. a) Fyfe, M. C. T.; Lowe, J. N.; Stoddart, J. F.; Williams, D. J. Org. Lett. 2000, 2, 12211224

b) Cantrill, S. J.; Youn, G. J.; Stoddart, J. F.; Williams, D. J. J. Org. Chem. 2001, 66, 6857-6872;

c) Balzani, V.; Clemente-leon, M.; Credi, A.; Lowe, J. N.; Badjic, J. D.; Stoddart, J. F.; Williams, D. J. Chem. Eur. J. 2003, 9, 5348-5360.

23. These units in acetone solution undergo complexation with the peripheral crown ether units and hence display time-averaged ${ }^{1} \mathrm{H}$ NMR signals that are shifted upfield relative to free 1 or its dibenzyl ester.

24. a) Gong, C.; Gibson, H. W. Angew. Chem. Int. Ed. 1997, 36, 2331-2333;

b) Gong, C.; Gibson, H. W. Angew. Chem. Int. Ed. 1998, 37, 310-314.

25. a) Feast, W. J.; Keeney, A. J.; Kenwright, A. M.; Parker, D. Chem. Comm. 1997, 17491750 
b) Higuchi, M.; Kanazawa, H.; Tsuruta, M.; Yamamoto, K. Macromolecules 2001, 34, 8847-8850;

c) Chikh, L.; Arnaud, X.; Guillermain, C.; Tessier, M.; Fradet, A. Macromol. Symp. 2003, 199, 209-221;

d) Kricheldorf, H. R. Macromol. Rapid Comm. 2007, 28, 1839-1870.

26. Stevenson, S.; Rice, G.; Glass, T.; Harich, K.; Cromer, F.; Jordan, M. R.; Craft, J.; Hadju, E.; Bible, R.; Olmstead, M. M.; Maltra, K.; Fisher, A. J.; Balch, A. L.; Dorn, H. C. Nature 1999, 401, 55-57.

27. Flory, P. J. Principles of Polymer Chemistry; Cornell University Press: Ithaca, NY, 1953; pp. 361-365.

28. Viscosity effects in one-dimensional (linear) supramolecular polymers: a) ref $18 \mathrm{e}$;

b) Söntjens, S. H. M.; Sijbesma, R. P.; van Genderen, M. H. P.; Meijer, E. W. Macromolecules 2001, 34, 3815-3818;

c) Gibson, H. W.; Yamaguchi, N.; Jones, J. W. J. Am. Chem. Soc. 2003, 125, 3522-3533;

d) ten Cate, A. T.; Kooijman, H.; Spek, A. L.; Sijbesma, R. P.; Meijer, E. W. J. Am. Chem. Soc. 2004, 126, 3801-3808;

e) Xu, H.; Rudkevich, D. M. Chem. Eur. J. 2004, 10, 5432-5442;

f) ref. $18 q$;

g) Niu, Z.; Huang, F.; Gibson, H. W. J. Am. Chem. Soc. 2011, 133, 2836-2839;

h) Xia, B.; Zheng, B.; Han, C.; Dong, S.; Zhang, M.; Hu, B.; Yu, Y.; Huang, F. Polym. Chem. 2013, 4, 2019-2024.

29. Elias, H.-G. Macromolecules; Plenum: New York, 1984; vol. 1, pp. 354-355. 
30. One example of this kind of polyelectrolyte is the sodium salt of poly(acrylic acid). In very dilute solutions, ionic species on polyelectrolyte chains repel each other, increasing the chain rigidity and expanding the polymer coil, with consequent increase in the viscosity. ${ }^{29}$

31. The [ $\eta]$ value of a hyperbranched poly(ethylene glycol dimethacrylate) having $M_{\mathrm{n}} 25$ kDa was $0.036 \mathrm{dL} / \mathrm{g}$ in THF (Guan, Z. J. Am. Chem. Soc. 2002, 124, 5616-5617).

32. a) Jikei, M.; Kakimoto, M.-A. Prog. Polym. Sci. 2001, 26, 1233-1285;

b) Pirrung, F. O. H.; Loen, E. M.; Noordam, A. Macromol. Symp. 2002, 187, 683-693.

33. Almost all previous supramolecular dendritic macromolecules have only one generation connected by nonocovalent interactions. ${ }^{11}$ One exception is a supramolelcuar hyperbranched polymer reported by us (Huang, F.; Gibson, H. W. J. Am. Chem. Soc. 2004, 126, 14738-14739). It was prepared by self-assembly of a covalent $\mathrm{AB}_{2}$ monomer containing one crown ether host moiety and two paraquat guest units.

34. a) Bryant, W. S.; Jones, J. W.; Mason, P. E.; Guzei, I.; Rheingold, A. L.; Fronczek, F. R.; Nagvekar, D. S.; Gibson, H. W. Org. Lett. 1999, 1, 1001-1004;

b) Huang, F.; Fronczek, F. R.; Gibson, H. W. J. Am. Chem. Soc. 2003, 125, 9272-9273;

c) Huang, F.; Gibson, H. W.; Bryant, W. S.; Nagvekar, D. S.; Fronczek, F. R. J. Am. Chem. Soc. 2003, 125, 9367-9371;

d) Huang, F.; Switek, K. A.; Zakharov, L. N.; Fronczek, F. R.; Slebodnick, C.; Lam, M.; Golen, J. A.; Bryant, W. S.; Mason, P.; Rheingold, A. L.; Ashraf-Khorassani, M.; Gibson, H. W. J. Org. Chem. 2005, 70, 3231-3241;

e) Huang, F.; Switek, K. A.; Gibson, H. W. Chem. Commun. 2005, 3655-3657; 
f) Gibson, H. W.; Wang, H.; Slebodnick, C.; Merola, J.; Kassel, S.; Rheingold, A. L. J. Org. Chem. 2007, 72, 3381-3393;

g) Pederson, A. M.-P.; Vetor, R. C.; Rouser, M. A.; Huang, F.; Slebodnick, C.; Schoonover, D. V.; Gibson, H. W. J. Org. Chem. 2008, 73, 5570-5573;

h) Pederson, A. M.-P.; Ward, E.; Schoonover, D. S.; Slebodnick, C.; Gibson, H. W. J. Org. Chem. 2008, 73, 9094-9101;

i) Zhang, M.; Yan, X.; Huang, F.; Niu, Z.; Gibson, H. W. Acc. Chem. Res. 2014, 47, 1995-2005.

TOC Graphic:

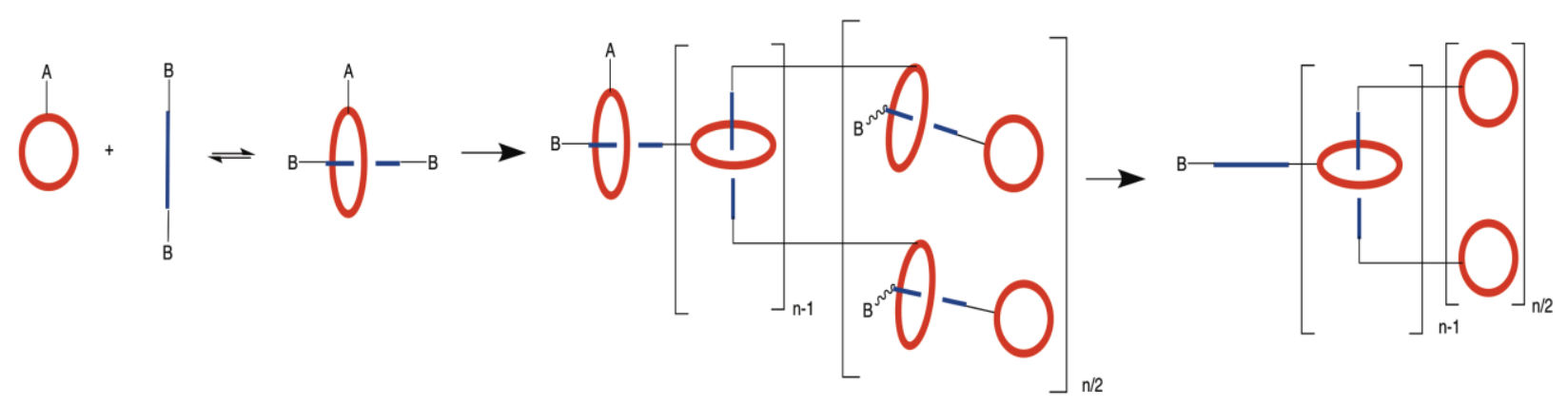




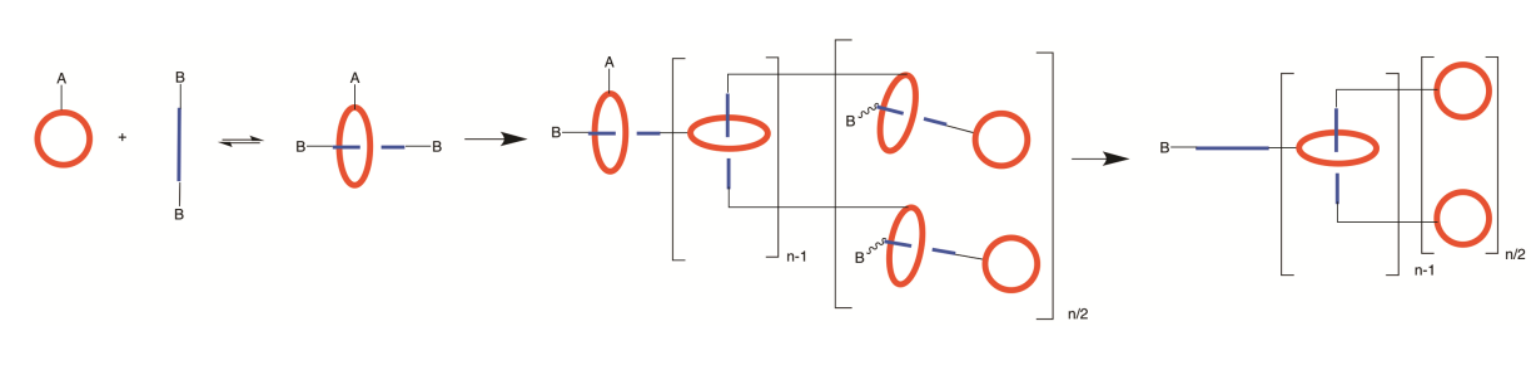

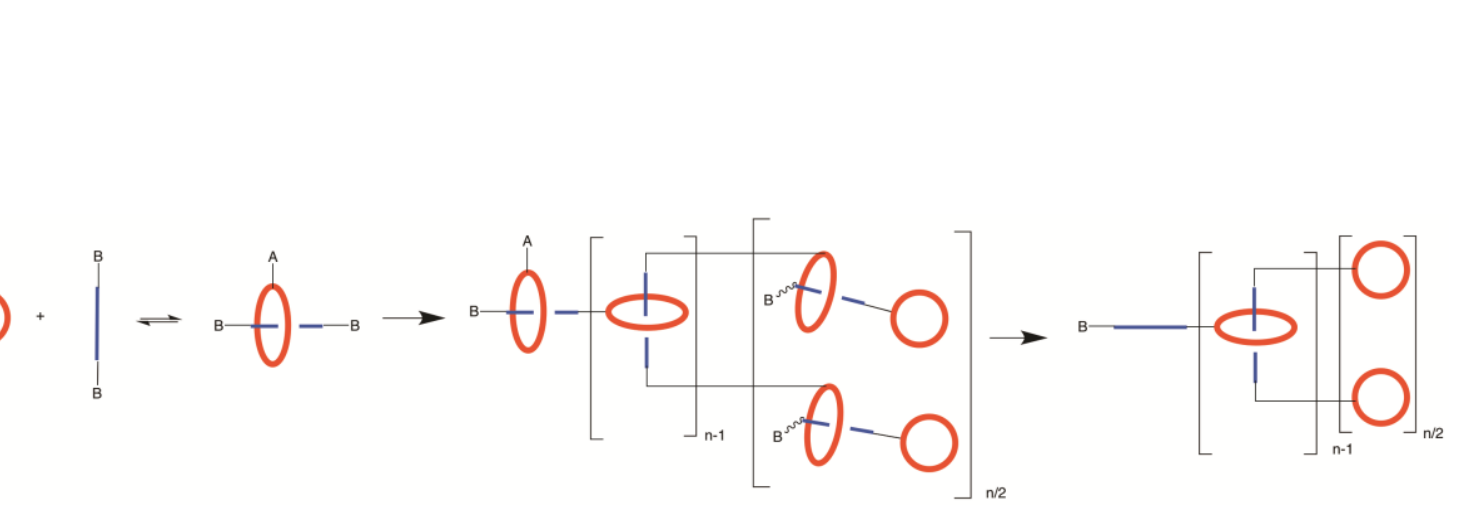

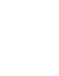

$$
\begin{aligned}
& \text { - } \\
& \text {. }
\end{aligned}
$$

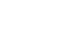

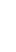

\section{*}

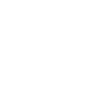$$
\text { ( }
$$$$
\text { (1) }
$$$$
\text { . }
$$

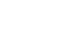

